\title{
Off-line algorithm for calculation of vertical tracer transport in the troposphere due to deep convection
}

\author{
D. A. Belikov ${ }^{1,2}$, S. Maksyutov ${ }^{1}$, M. Krol ${ }^{3,4,5}$, A. Fraser $^{6}$, M. Rigby ${ }^{7}$, H. Bian ${ }^{8}$, A. Agusti-Panareda ${ }^{9}$, D. Bergmann ${ }^{10}$, \\ P. Bousquet ${ }^{11}$, P. Cameron-Smith ${ }^{10}$, M. P. Chipperfield ${ }^{12}$, A. Fortems-Cheiney ${ }^{11}$, E. Gloor ${ }^{12}$, K. Haynes ${ }^{13,14}$, P. Hess ${ }^{15}$, \\ S. Houweling ${ }^{3,4}$, S. R. Kawa ${ }^{8}$, R. M. Law ${ }^{14}$, Z. Loh $^{14}$, L. Meng ${ }^{16}$, P. I. Palmer ${ }^{6}$, P. K. Patra ${ }^{17}$, R. G. Prinn ${ }^{18}$, R. Saito ${ }^{17}$, \\ and C. Wilson ${ }^{12}$ \\ ${ }^{1}$ Center for Global Environmental Research, National Institute for Environmental Studies, 16-2 Onogawa, Tsukuba, Ibaraki, \\ 305-8506, Japan \\ ${ }^{2}$ Division for Polar Research, National Institute of Polar Research, 10-3, Midoricho, Tachikawa, Tokyo 190-8518, Japan \\ ${ }^{3}$ SRON Netherlands Institute for Space Research, Sorbonnelaan 2, 3584 CA Utrecht, The Netherlands \\ ${ }^{4}$ Institute for Marine and Atmospheric Research Utrecht (IMAU), Princetonplein 5, 3584 CC Utrecht, The Netherlands \\ ${ }^{5}$ Wageningen University and Research Centre, Droevendaalsesteeg 4, 6708 PB Wageningen, The Netherlands \\ ${ }^{6}$ School of GeoSciences, University of Edinburgh, King's Buildings, West Mains Road, Edinburgh, EH9 3JN, UK \\ ${ }^{7}$ School of Chemistry University of Bristol Bristol, UK \\ ${ }^{8}$ Goddard Earth Sciences and Technology Center, NASA Goddard Space Flight Center, Code 613.3, Greenbelt, MD 20771, \\ USA \\ ${ }^{9}$ ECMWF, Shinfield Park, Reading, Berks, RG2 9AX, UK \\ ${ }^{10}$ Atmospheric, Earth, and Energy Division, Lawrence Livermore National Laboratory, 7000 East Avenue, Livermore, \\ CA94550, USA \\ ${ }^{11}$ Universite de Versailles Saint Quentin en Yvelines (UVSQ), GIF sur YVETTE, France \\ ${ }^{12}$ Institute for Climate and Atmospheric Science, School of Earth and Environment, University of Leeds, Leeds, LS2 9JT, UK \\ ${ }^{13}$ Department of Atmospheric Science, Colorado State University, Fort Collins, CO, 80523, USA \\ ${ }^{14}$ Centre for Australian Weather and Climate Research, CSIRO Marine and Atmospheric Research, 107-121 Station St., \\ Aspendale, VIC 3195, Australia \\ ${ }^{15}$ Cornell University, 2140 Snee Hall, Ithaca, NY 14850, USA \\ ${ }^{16}$ Department of Geography and Environmental Studies Program, Western Michigan University, Kalamazoo, MI 49008, USA \\ ${ }^{17}$ Research Institute for Global Change/JAMSTEC, 3173-25 Showa-machi, Yokohama, 236-0001, Japan \\ ${ }^{18}$ Center for Global Change Science, Building 54, Massachusetts Institute of Technology, Cambridge, MA, 02139, USA
}

Correspondence to: D. A. Belikov (dmitry.belikov@nies.go.jp)

Received: 25 May 2012 - Published in Atmos. Chem. Phys. Discuss.: 14 August 2012 Revised: 11 January 2013 - Accepted: 14 January 2013 - Published: 1 February 2013

\begin{abstract}
A modified cumulus convection parametrisation scheme is presented. This scheme computes the mass of air transported upward in a cumulus cell using conservation of moisture and a detailed distribution of convective precipitation provided by a reanalysis dataset. The representation of vertical transport within the scheme includes entrainment and detrainment processes in convective updrafts and downdrafts. Output from the proposed parametrisation scheme is employed in the National Institute for Environmental Studies (NIES) global chemical transport model driven by JRA-
\end{abstract}

25/JCDAS reanalysis. The simulated convective precipitation rate and mass fluxes are compared with observations and reanalysis data. A simulation of the short-lived tracer ${ }^{222} \mathrm{Rn}$ is used to further evaluate the performance of the cumulus convection scheme. Simulated distributions of ${ }^{222} \mathrm{Rn}$ are evaluated against observations at the surface and in the free troposphere, and compared with output from models that participated in the TransCom- $\mathrm{CH}_{4}$ Transport Model Intercomparison. From this comparison, we demonstrate that the 
proposed convective scheme in general is consistent with observed and modeled results.

\section{Introduction}

Deep cumulus convection (DCC) plays an important role in the hydrological cycle of the climate system, the dynamics of the atmospheric circulation and the transport of trace gases within the troposphere. Indeed, the major sources of uncertainty in climate models are associated with the representation of cumulus convection. DCC also affects atmospheric chemistry indirectly through latent heating and contributions to the budgets of solar and infrared radiation (Lawrence and Salzmann, 2008).

Deep convective updrafts extend from the surface to the upper troposphere, with typical vertical velocities of several meters per second. These rapid updrafts are accompanied by rapid downdrafts, which together result in considerable vertical mixing and deliver polluted boundary layer air to the middle and upper troposphere (Feichter and Crutzen, 1990). Air masses associated with DCC can reach altitudes above the zero radiative heating level in the tropical tropopause layer, allowing detrained air to slowly ascend into the lower stratosphere (Folkins et al., 1999; Fueglistaler et al., 2004). The rapid updrafts associated with DCC occasionally even cause direct penetration of tropospheric air into the lower stratosphere, which can last up to several hours. After rapid ascent from the surface layer in DCC, tracers can be advected over long distances by the strong zonal winds that prevail in the upper troposphere (Allen et al., 1996; Zaucker et al., 1996). This relationship illustrates the important role that convection plays in long-range tracer transport. Along with largescale advection and vertical diffusion, cumulus convection is one of the most important transport processes affecting atmospheric tracers.

General circulation models (GCMs) and chemical transport models (CTMs) are unable to explicitly resolve convection due to its small spatial scale relative to synoptic-scale processes and the resolution of model grids. Cumulus convection must therefore be parametrised in global models. This has motivated the development of a large number of different parametrisations of cumulus convection. Of these parametrisations, those based on plume ensemble formulations and those based on bulk formulations are the most widely used in tracer transport applications (Arakawa, 2004; Lawrence and Rasch, 2005). Regardless of the approach used in a cumulus convection parametrisation, a set of equations must be solved. Online coupling of a CTM with a GCM can offer significant advantages if both models are running simultaneously to calculate cumulus convection parameters at every time step. This approach allows tracer transport to be calculated within the CTM while the GCM provides the meteorological variables (including parametrised fields) that are used to drive tracer transport.
The options available for on-line CTMs are generally not available for off-line models, which are operated using a limited set of time-averaged, predefined meteorological parameters taken from a gridded reanalysis dataset. Reanalysis datasets often do not contain all fields that are necessary for tracer transport modelling, such as parameters associated with subgrid-scale mixing; consequently, the implementation of parametrisation schemes in off-line CTMs presents a significant challenge (Mahowald et al., 1995, 1997).

Previous studies have demonstrated that transport model simulations of the distribution of ${ }^{222} \mathrm{Rn}$ fields are strongly sensitive to the parametrisation used to represent cumulus convection (Brost and Chatfield, 1989; Jacob et al., 1997). ${ }^{222} \mathrm{Rn}$ is almost completely insoluble in water, so that it is removed from the atmosphere solely by radioactive decay. The sensitivity to the parametrisation schemes and the relatively simple life cycle make ${ }^{222} \mathrm{Rn}$ an excellent tracer for evaluating the performance of transport models in simulations of short-range transport over continental and remote oceanic regions (Allen et al., 1996; Dentener et al., 1999).

Although ${ }^{222} \mathrm{Rn}$ has long been recognized as a useful tracer for evaluating the performance of transport models, it has several disadvantages related to source uncertainties. The most frequently used fluxes (Jacob et al., 1997) are accurate to within $25 \%$ globally and to within a factor of two regionally. The main factors controlling spatial variations in ${ }^{222} \mathrm{Rn}$ flux are depth of aerated soil, soil ${ }^{226} \mathrm{Ra}$ concentrations $\left({ }^{222} \mathrm{Rn}\right.$ precursor) and emanation rate. The main factors determining temporal variations are precipitation and soil moisture. Shallow water tables and frost cover can be a cause of temporal but also of spatial variation (Conen, 2004).

Previous studies have performed detailed examinations of the influence of convective mixing on ${ }^{222} \mathrm{Rn}$ and other shortlived tracers' distributions in the troposphere (Mahowald et al., 1995, 1997; Allen et al., 1996; Li and Chang, 1996; Jacob et al., 1997; Rasch et al., 1997; Stockwell et al., 1998; Olivié et al., 2004; Zhang at el., 2008). Although measurements of atmospheric radon concentration by distributed observatories provide good reference points for model evaluation, there remains a lack of suitable measurements of radon concentration in the free troposphere (Zhang et al., 2008). Recent studies (e.g., Tost et al., 2010) have focused on evaluating how the formulations of convective schemes influence simulated tracer distributions and quantifying uncertainties in trace gases $\left(\mathrm{H}_{2} \mathrm{O},{ }^{222} \mathrm{Rn}, \mathrm{CO}, \mathrm{HCHO}, \mathrm{HNO}_{3}\right.$ and $\left.\mathrm{O}_{3}\right)$ due to the parametrisation of convection. Feng et al. (2011) investigated the performance of cloud convection and tracer transport in a global off-line 3-D chemical transport model and diagnosed the updraft mass flux, convective precipitation and cloud top height performing various model simulations using different meteorological (re)analyses.

Uncertainties in convective transport processes may also be quantified by comparing the output of a variety of models that employ a range of cumulus parametrisations. Although the primary focus of the TransCom- $\mathrm{CH}_{4}$ Transport Model 
Intercomparison (TMI) was $\mathrm{CH}_{4}$, the contributing models also simulated the distributions of several auxiliary tracers, including ${ }^{222} \mathrm{Rn}$ (Patra et al., 2011). The TransCom- $\mathrm{CH}_{4}$ TMI simulation of ${ }^{222} \mathrm{Rn}$ is similar to the simulation protocol specified by Jacob et al. (1997). The surface flux of ${ }^{222} \mathrm{Rn}$ is set to $1.66 \times 10^{-20} \mathrm{~mol} \mathrm{~m}^{-2} \mathrm{~s}^{-1}$ for land areas between $60^{\circ} \mathrm{S}$ and $60^{\circ} \mathrm{N}$, to $8.3 \times 10^{-23} \mathrm{~mol} \mathrm{~m}^{-2} \mathrm{~s}^{-1}$ for oceans between $60^{\circ} \mathrm{S}$ and $60^{\circ} \mathrm{N}$ and to $8.3 \times 10^{-23} \mathrm{~mol} \mathrm{~m}^{-2} \mathrm{~s}^{-1}$ for arctic regions $\left(60-70^{\circ} \mathrm{N}\right)$. This surface flux distribution ensures consistency with radon simulations conducted in conjunction with the World Climate Research Programme (WCRP) and other previous studies (e.g., Mahowald et al., 1997; Zhang et al., 2008).

This work describes an adaptation of the cumulus convection parametrisation scheme used in the National Institute for Environmental Studies (NIES) transport model. This adaptation aims to improve model performance by achieving more realistic simulations of vertical mixing and tracer transport. The paper is organized as follows. The DCC parametrisation and model formulation are described in Sect. 2. The reanalysis convective precipitation rates and simulated convective mass fluxes are validated against reanalysis and observational data in Sect. 3. The simulated surface concentrations and vertical profiles of ${ }^{222} \mathrm{Rn}$ are evaluated relative to in situ observations from aircraft and surface stations and compared with output from models that contributed to the TransCom$\mathrm{CH}_{4} \mathrm{TMI}$ in Sect. 4. Here we also analyzed the performance of the other TransCom- $\mathrm{CH}_{4}$ transport models. The results and conclusions of the study are summarized in Sect. 5.

\section{Model formulation}

\subsection{Off-line calculation of convective mass flux}

In this work, the method for calculating cumulus convective vertical mass fluxes from precipitation rates is modified from that developed by Austin and Houze (1973) and first implemented by Feichter and Crutzen (1990). The method is built on the basic assumption that the mass of air transported upward in a cumulus cell is related to the amount of precipitation that the cell produces. This premise is based on empirical data and simplified dynamic cell model. The upward mass transport can therefore be computed from conservation of water if the amount of precipitation generated by the cell is known. Following Austin and Houze (1973), the mass of air $M_{\mathrm{U}}$ rising through the level of maximum upward flux $\zeta$ is given by

$M_{\mathrm{U}}(\zeta)=C / \int_{z_{\text {base }}}^{z_{\text {top }}} f(z)\left[E_{\mathrm{U}}\left(q_{\mathrm{E}}-q_{\mathrm{U}}\right)-\frac{\mathrm{d} q_{\mathrm{U}}}{\mathrm{d} z}\right] \mathrm{d} z$.

The parameters of Eq. (1) are defined as follows: $C$ - total amount of water condensed in the convective cloud cell [kg], $f(z)-$-shape function, $E_{\mathrm{U}}$ - updraft entrainment rate $\left[\mathrm{km}^{-1}\right], q_{\mathrm{E}}-$ mixing ratio of water in the environment, $q_{\mathrm{U}}$ - mixing ratio of water in the updraft, $z$ - vertical level [m], $z_{\text {base }}, z_{\text {top }}$ - altitudes of the base and top levels of the cloud cell $[\mathrm{m}]$.

The mass of air rising vertically through any level $z$ is then parametrised as

$M_{\mathrm{U}}(z)=M_{\mathrm{U}}(\zeta) f(z)$,

where the level of maximum upward flux $\zeta$ is approximated from observations according to the expression

$\zeta=z_{\text {base }}+\alpha\left(z_{\text {top }}-z_{\text {base }}\right)$.

The parameter $\alpha$ is set equal 0.75 in the tropics and 0.5 in midlatitudes (Austin and Houze, 1973). Following Feichter and Crutzen (1990), and Austin and Houze (1973), the shape function $f(z)$ is defined as

$f(z)=\left\{\begin{array}{l}\frac{1}{2-E_{\mathrm{U}}}\left[2 \exp \left(E_{\mathrm{U}}(z-\zeta)\right)-E_{\mathrm{U}} \exp (2(z-\zeta))\right], \\ z_{\text {base }}<z<\zeta \\ 1-\left(z-\zeta / z_{\text {top }}-\zeta\right)^{2}, \zeta \leq z<z_{\text {top }}\end{array}\right.$

The entrainment rate is assumed to remain constant with altitude (Austin and Houze, 1973), and is defined as

$E_{\mathrm{U}}=\frac{a}{0.13\left(z_{\text {top }}-z_{\text {base }}-1\right)}\left[\mathrm{km}^{-1}\right], a=0.2$.

The total amount of water condensed in the cloud during the life-cycle of the convective cell is given by

$C=x_{1} \cdot P_{\mathrm{c}}$,

where $P_{\mathrm{c}}$ denotes the total amount of convective precipitation at the surface $[\mathrm{kg}]$ and $x_{1}$ is a constant in the range $2 \ldots 10$. We selected $x_{1}=3$ to be consistent with (Austin and Houze, 1973), who recommend value between 3 and 4 .

In tracer transport applications, the vertical convective mass flux $\mathrm{MF}_{\mathrm{U}}$ is of primary practical importance. This flux can be determined as $\mathrm{MF}_{\mathrm{U}}=M_{\mathrm{U}} /(S \cdot \Delta t)$, where $S$ is the area of the model grid cell, and $\Delta t$ is the time step used in the model integration. The total amount of convective precipitation can be similarly determined as $P_{\mathrm{c}}=P_{\mathrm{R}} \cdot S \cdot \Delta t$, where $P_{\mathrm{R}}$ is the surface convective precipitation rate $\left[\mathrm{kg} \mathrm{m}^{-2} \mathrm{~s}^{-1}\right]$ provided by a reanalysis dataset. The equation for the vertical convective mass flux $\mathrm{MF}_{\mathrm{U}}$ is then

$\mathrm{MF}_{\mathrm{U}}(\zeta)=x_{1} \cdot P_{\mathrm{R}} / \int_{\text {bbase }}^{z_{\text {top }}} f(z)\left[E_{\mathrm{U}}\left(q_{\mathrm{E}}-q_{\mathrm{U}}\right)-\frac{\mathrm{d} q_{\mathrm{U}}}{\mathrm{d} z}\right] \mathrm{d} z$.

By contrast, the updraft mass flux $\mathrm{MF}_{\mathrm{U}}$ in the original Kuotype scheme (Tiedtke, 1989) implemented in previous version of NIES TM (Maksyutov et. al., 2008) is determined as 
the ratio of low-level moisture convergence $\left(M_{\mathrm{L}}\right)$ to the mixing ratio of water vapour at cloud base $\left(q_{\text {base }}\right)$ :

$\mathrm{MF}_{\mathrm{U}}=M_{\mathrm{L}} / q_{\text {base }}$.

$M_{\mathrm{L}}$ is obtained by integrating the total horizontal moisture convergence below the cloud base:

$M_{\mathrm{L}}=-\left[\int_{\sigma_{C}}^{1} \nabla_{\sigma}\left(p_{\mathrm{S}} \cdot \boldsymbol{V} \cdot q\right) \mathrm{d} \sigma-M_{\mathrm{c}}\right]+S_{\text {evap }}$,

where $\boldsymbol{V}$ is the horizontal wind velocity vector with longitudinal and latitudinal components $(u, v) ; \sigma=p / p_{\mathrm{s}}$, where $p$ and $p_{\mathrm{s}}$ are the atmospheric and the surface pressures; $\sigma_{\mathrm{c}}$ is the cloud base level, $S_{\text {evap }}$ is the surface evaporation. The moisture divergence term is corrected for non-zero divergence of the air mass $M_{\mathrm{c}}$ to account for deviation from the mass conservation in the wind data

$M_{\mathrm{c}}=\int_{\sigma_{\mathrm{c}}}^{1} q \cdot \nabla_{\sigma}\left(p_{\mathrm{S}} \cdot \boldsymbol{V}\right) \mathrm{d} \sigma$.

This off-line algorithm based on moisture balance (Eqs. 810) has several limitations. Firstly, to determine updraft mass flux we should find the total horizontal moisture convergence (Eq. 9) and the divergence of the air mass (Eq. 10). Calculation of these values in the offline model induces significant errors, as required to implement divergence operator to fields distorted by additional spatial and temporal interpolations (i.e. between the reanalysis model grid, the reanalysis data grid and the transport model grid). For example, Global Point Value (GPV) a special product prepared by the Japan Meteorological Agency Global Circulation Model (JMA-GSM), which is a high-resolution global atmospheric circulation model developed by the Japan Meteorological Agency (JMA) and the Meteorological Research Institute (MRI) of Japan. The current version of the model uses a reduced Gaussian grid TL959L60 with a resolution of approximately $20 \mathrm{~km}$ in the horizontal and 60 layers up to $0.1 \mathrm{hPa}$ in the vertical (Mizuta et al., 2006). However, for users this meteorological dataset is available with a resolution of $0.5^{\circ} \times 0.5^{\circ}$ for 21 pressure levels.

Secondly, the scheme requires additionally using surface evaporation data $S_{\text {evap. }}$. Usually, this data are different from the reanalysis implemented for advection and may introduce inconsistencies in the transport. Thus, implementation of parameterisation based on moisture balance (Eqs. 8-10) in offline model induces more errors in estimation of updraft mass flux than the more straightforward approach of Eq. (7).

The detrainment rate of mass from convective plumes due to turbulent mass exchange at the edges of the cloud is defined to be proportional to $\mathrm{MF}_{\mathrm{U}}$ (Turner, 1963; Tiedtke, 1989):

$D_{\mathrm{U}}=\delta_{\mathrm{U}} \cdot \mathrm{MF}_{\mathrm{U}}$.
The entrainment and detrainment rate coefficients are the same as those employed by Tiedtke (1989): $\varepsilon_{\mathrm{U}}=\delta_{\mathrm{U}}=1 \times$ $10^{-4}\left[\mathrm{~m}^{-1}\right]$.

Following Johnson (1976), the downdraft mass flux is defined to be directly proportional to the upward mass flux:

$\mathrm{MF}_{\mathrm{D}}^{\mathrm{t}}=\gamma \mathrm{MF}_{\mathrm{U}}^{\mathrm{b}}$,

where $M F_{\mathrm{D}}^{\mathrm{t}}$ is the downdraft mass flux at cloud top, $\mathrm{MF}_{\mathrm{U}}^{\mathrm{b}}$ is the updraft mass flux at cloud base and $\gamma$ is a parameter equal to -0.2 (Tiedtke, 1989). The parametrisation used for entrainment and detrainment in downdrafts is identical to that used in updrafts, with entrainment and detrainment rate coefficients $\varepsilon_{\mathrm{D}}=\delta_{\mathrm{D}}=2 \times 10^{-4}\left[\mathrm{~m}^{-1}\right]$ (Tiedtke, 1989).

Mixing ratio of water in the environment and in the updraft $q_{\mathrm{E}}, q_{\mathrm{U}}$ necessary for Eq. (8) are calculated using water mixing ratio, the air temperature and pressure supplied by meteorological reanalysis.

Following the determination of the updraft and downdraft mass fluxes, tracer transport by cumulus convection is simulated using the explicit scheme presented by Maksyutov et al. (2008). The tracer concentration is estimated at each level of the convective column sequentially from bottom to top using known updraft, downdraft, entrainment and detrainment mass fluxes along with differences in tracer concentration differences between the convective column and the ambient environment. The tracer tendency in the surrounding environmental air is then calculated according to the same tracer fluxes.

The implementation of this convective parametrisation scheme additionally requires a priori knowledge of convective precipitation rate at the surface and the levels of cloud top and cloud base. These parameters must be supplied by a meteorological reanalysis dataset or calculated using the Kuo parametrisation scheme (Kuo, 1965, 1974). This latter technique has been implemented in the National Center for Atmospheric Research/Pennsylvania State University Mesoscale Model (MM5), as discussed by Grell et al. (1994). The level of the cloud base $\left(\sigma_{\mathrm{b}}\right)$ is defined as the lowest level where condensation would occur during dry adiabatic ascent, which is often referred to as the lifting condensation level. This level is identified by slightly perturbing the humidity and temperature fields at levels below $700 \mathrm{hPa}$ and determining where condensation would occur if the perturbed air parcel were lifted adiabatically. The level of the cloud top is identified based on the assumptions that enthalpy is greater inside clouds than outside clouds and that enthalpy decreases upward due to entrainment and detrainment. At the level of cloud top, the total thermodynamic energy inside the cloud should equal the total thermodynamic energy outside; accordingly, cloud top is defined as the level of zero buoyancy, with a minor overshoot of $3 \mathrm{~K}$ that accounts for the upward momentum of the convective updraft (Kuo, 1974). The upper boundary of the cloud is confined to altitudes below the $150 \mathrm{hPa}$ isobaric level. Clouds with thicknesses less than $\Delta \sigma=0.1$ are excluded from consideration. 


\subsection{The NIES global tracer transport model}

The cumulus parametrisation scheme, in which the vertical convective mass flux calculated using Eq. (7) is incorporated into the National Institute for Environmental Studies off-line global Transport Model (NIES TM). The goal of this parametrisation is to improve the accuracy of NIES TM simulations of vertical tracer transport in the troposphere by improving the representation of tracer transport in DCC.

The NIES TM is designed to simulate natural and anthropogenic synoptic-scale variations in atmospheric constituents at diurnal, seasonal and interannual timescales. The model uses a mass-conservative flux-form formulation that consists of a third-order van Leer advection scheme and a horizontal dry-air mass flux correction (Heimann and Keeling, 1989). The horizontal latitude-longitude grid is a reduced rectangular grid (i.e., the grid size is doubled several times approaching the poles; Kurihara, 1965), with an initial spatial resolution of $2.5^{\circ} \times 2.5^{\circ}$ (Belikov et al., 2011).

The parametrisation of turbulent diffusivity follows the approach used by Hack et al. (1993), with transport processes in the planetary boundary layer (PBL) and free troposphere evaluated separately. Turbulent diffusivity above the top of the PBL is calculated from local stability as a function of the Richardson number and is set to a constant value of $40 \mathrm{~m}^{2} \mathrm{~s}^{-1}$ under an assumption of well-mixed air below the PBL top. Three-hourly PBL heights are taken from the European Centre for Medium-Range Weather Forecasts (ECMWF) ERA-Interim Reanalysis.

\section{Datasets}

\subsection{Evaluation of convective precipitation data}

As discussed above, the convective parametrisation scheme additionally requires a priori knowledge of the convective precipitation rate at the surface and the altitudes of cloud top and cloud base. This information may be supplied by a meteorological reanalysis dataset. All meteorological data used in the NIES TM simulations discussed in this paper (except PBL height) are provided by a reanalysis dataset produced by the Japan Meteorological Agency (JMA) and the Central Research Institute of Electric Power Industry (CRIEPI). This dataset combines the Japanese 25-yr Reanalysis (JRA25), which covers the 25-yr time period from 1 January 1979 through 31 December 2004, and the JMA Climate Data Assimilation System (JCDAS), which covers the time period from 1 January 2005 to the present (Onogi et al., 2007). The JRA-25/JCDAS data is provided on a T106 Gaussian horizontal grid $(320 \times 160$ gridcells $)$ with 40 hybrid sigmapressure levels.

The JRA-25/JCDAS convective precipitation data is evaluated by comparing it with monthly mean data from the global Climate Prediction Center (CPC) Merged Analysis of Precipitation (CMAP) and special product data from the Modern Era Retrospective-analysis for Research and Applications (MERRA). The CMAP dataset has been constructed by merging several individual data sources with different characteristics (Xie and Arkin, 1997). These data sources include monthly analyses from the Global Precipitation Climatology Centre, observations provided by multiple satellites and precipitation forecasts from the National Centers for Environmental Prediction and National Center for Atmospheric Research (NCEP/NCAR) reanalysis. The MERRA dataset has been produced using the National Aeronautics and Space Administration (NASA) global data assimilation system, which employs NASA Goddard Earth Observing System global atmospheric model version 5 (GEOS-5). Using a non-hydrostatic finite-volume dynamical core coupled with advances in the moist physics and convective parameterization the model has been used to perform cloud-system resolving experiments at resolutions as fine as 3.5- to 14km globally (Putman and Suarez, 2011). This data assimilation system incorporates information from a variety of modern observing systems (such as the Earth Observing System, a coordinated series of polar-orbiting and low-inclination satellites that provides long-term global observations of the climate system) into a reanalysis framework for climate applications (Wong et al., 2011).

Figure 1 shows zonal mean convective precipitation (CP) and total precipitation (TP) rates $\left(\mathrm{mm} \mathrm{d}^{-1}\right)$ from the JRA25/JCDAS, MERRA and CMAP datasets respectively averaged for June-July-August (JJA) and December-JanuaryFebruary (DJF) 2006. The JRA-25/JCDAS dataset generally captures the latitudinal variation of $\mathrm{CP}$ reported in the MERRA and in good agreement with TP from CMAP datasets in tropical regions, where fraction of convective precipitation in total precipitation budget is quite large. JRA25/JCDAS convective precipitation rate even exceeds total CMAP precipitation. While the estimates from CMAP and MERRA bracket that from JRA-25/JCDAS in mid-latitudes. The JRA-25/JCDAS CP and CMAP TP are consistent in shape and only slightly different in magnitude in the tropics, whereas the MERRA dataset is biased low compared to the other estimates by $2 \mathrm{~mm} \mathrm{~d}^{-1}$ during both seasons.

All three datasets indicate seasonal and geographic variations in precipitation (Table 1). CP and TP is consistently higher in the Northern Hemisphere than in the Southern Hemisphere and also consistently higher during the boreal summer season (JJA) than during boreal winter (DJF). Hot weather during the boreal summer season leads to frequent convective storms in northern temperate latitudes (Fig. 2). The largest amounts of $\mathrm{CP}$ occur in equatorial areas and over India and Southeast Asia during the monsoon season (Myoung and Nielsen-Gammon, 2010). The potential for DCC over the ocean persists throughout the night, and convective cells over the ocean commonly reach altitudes in the upper troposphere (Schumacher and Houze, 2003). The seasonal 

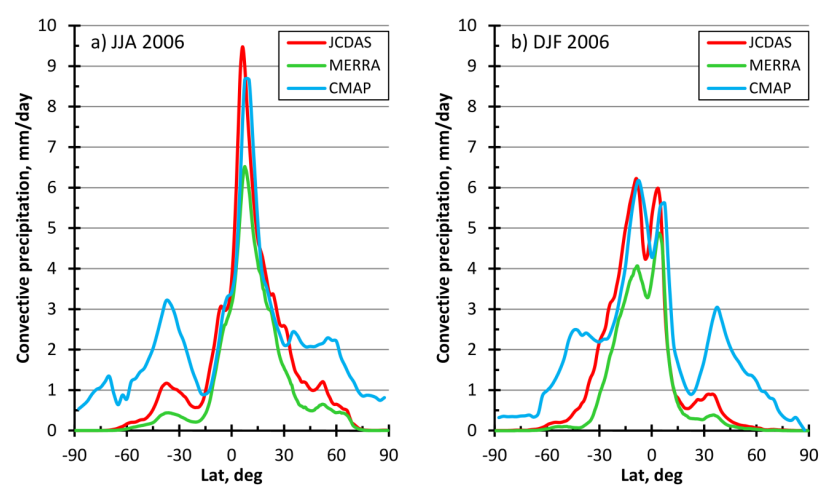

Fig. 1. Zonal mean convective precipitation from the JRA25/JCDAS, MERRA and CMAP total precipitation $\left(\mathrm{mm} \mathrm{d}^{-1}\right)$ averaged over (a) JJA and (b) DJF 2006.

Table 1. Seasonal mean convective precipitation and total precipitation rates $\left(\mathrm{mm} \mathrm{d}^{-1}\right)$ from the JRA-25/JCDAS, MERRA and CMAP datasets respectively averaged globally, over the Northern Hemisphere $(\mathrm{NH})$ and over the Southern Hemisphere (SH).

\begin{tabular}{lcccccc}
\hline & \multicolumn{2}{c}{ JRA-25/JCDAS } & \multicolumn{2}{c}{ MERRA } & \multicolumn{2}{c}{ CMAP } \\
\cline { 2 - 7 } & JJA & DJF & JJA & DJF & JJA & DJF \\
\hline Average (Global) & 1.50 & 1.27 & 1.02 & 0.83 & 2.20 & 2.00 \\
Average (NH) & 2.22 & 0.85 & 1.60 & 0.63 & 2.75 & 1.80 \\
Average (SH) & 0.77 & 1.69 & 0.45 & 1.04 & 1.66 & 2.21 \\
\hline
\end{tabular}

variability of convective rainfall is small over warm seas and oceans.

\subsection{Evaluation of the simulated convective mass flux}

The MERRA special products dataset, which has been developed in conjunction with the chemistry community, provides support for chemistry transport modelling (Wong et al., 2011). This dataset includes a number of meteorological fields that are necessary for tracer transport simulations, including fields that describe convective motion (such as upward convective mass flux). This reanalysis dataset can therefore be used to evaluate simulated convective mass fluxes calculated using Eq. (7). However, the MERRA reanalysis also depends on a model that includes a parameterization of convective processes. Although meteorological fields in the reanalysis are optimized against observations they are still not independent of the specific parameterization scheme. This is therefore more a comparison between the results of different parameterization schemes.

The convective mass flux calculated by the proposed convection scheme is generally in good agreement with MERRA year-round in the tropics (Fig. 3). This agreement between the two datasets is particularly good over Southeast Asia, the Pacific coast of Central America and the tropical Atlantic Ocean. The proposed convection scheme underesti-

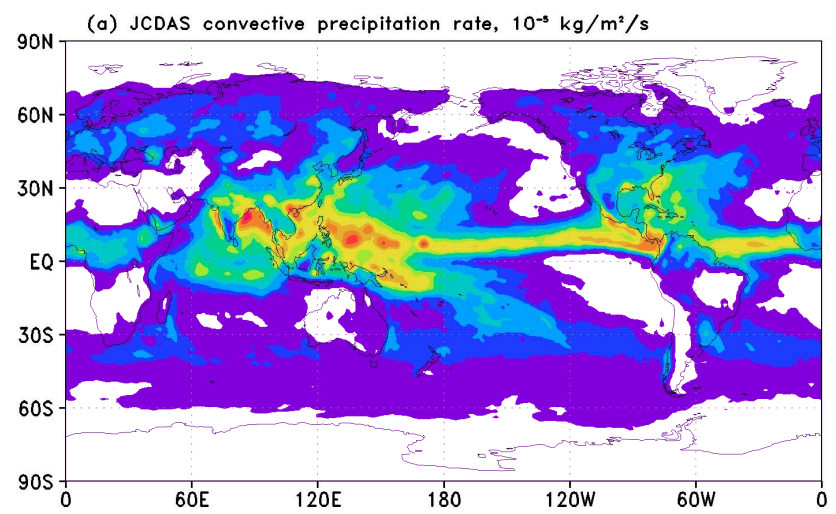

(b) MERRA convective precipitation rate, $10^{-s} \mathrm{~kg} / \mathrm{m}^{2} / \mathrm{s}$
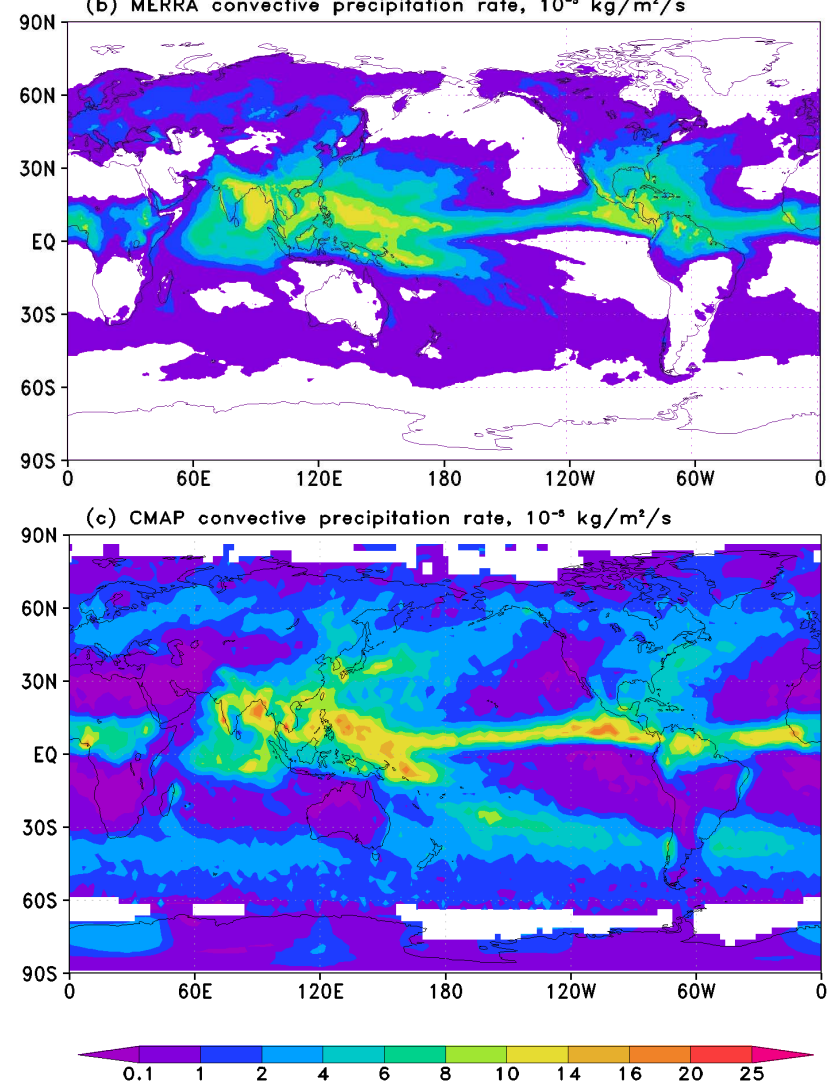

Fig. 2. Seasonal (JJA) mean convective precipitation rates from the (a) JRA-25/JCADS, (b) MERRA and (c) CMAP total precipitation rates $\left(10^{-5} \mathrm{~kg} \mathrm{~m}^{-2} \mathrm{~s}^{-1}\right)$ for 2006 .

mates convective mass fluxes over the oceanic regions of the western coastlines of North and South America, Africa and Australia, and in the Southern Ocean off the northern coast of Antarctica. The differences over mid-latitude oceanic regions are larger in both hemispheres during DJF (boreal winter/austral summer) than during JJA. The agreement between the two datasets is better over the continents. Both datasets indicate that convective mass fluxes are fairly evenly distributed over land areas, and discrepancies in the simulated intensity of convective mixing are much lower. 

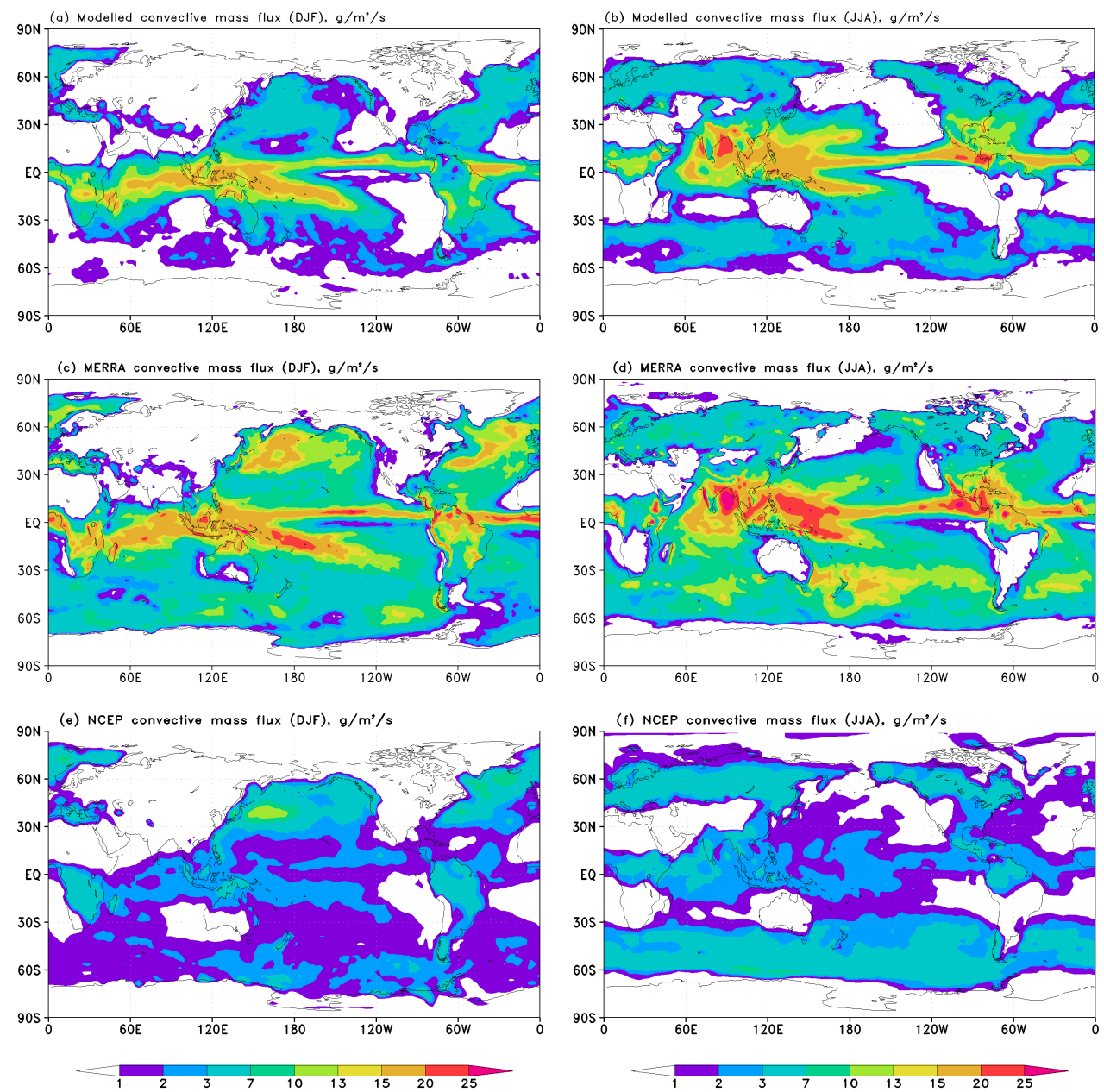

Fig. 3. DJF and JJA seasonal mean convective mass fluxes $\left(\mathrm{g} \mathrm{m}^{-2} \mathrm{~s}^{-1}\right)$ simulated by the NIES TM model outfitted with the proposed convection scheme $(\mathbf{a}, \mathbf{b})$, from the MERRA dataset $(\mathbf{c}, \mathbf{d})$, calculated by the original Kuo-type scheme according to Eqs. (8-10) using NCEP reanalysis $(\mathbf{e}, \mathbf{f})$.

Convective precipitation rates in the JRA-25/JCDAS dataset used to drive the model and the MERRA dataset agree most closely over the continents and tropical oceans (Fig. 2), exactly where the two convective flux datasets agree. The regional mismatches in intensity described above indicate that convective precipitation may not always accompany upward convective mass flux. Equation (7) represents only deep convection accompanied by convective precipitations, however precipitation occurs only when a cloud water threshold is exceeded, so convection may exist without precipitation. Moreover, convective upward and fall of convective precipitations may occur at a different moment of time or in a different grid cell if the convective column moves. Thus, the proposed convection scheme successfully captures most of the large-scale upward convective mass flux that is accompanied by convective precipitation, but does not appear to reproduce smaller intensity upward fluxes.
Bottom panel (Fig. 3e, f) shows upward convective mass flux calculated by previous version of NIES TM (NIES-05, described by Maksyutov et al., 2008) with the original Kuotype scheme (8-10) using NCEP reanalysis. In general the parameterization is able to reproduce convective mass flux, but underestimates intensity in comparison to MERRA and proposed scheme. It is especially visible in tropical regions, where significant contribution is coming from second term of Eq. (9) the surface evaporation $S_{\text {evap }}$. This term is used to compensate insufficient reproduction of moisture convergence due to imbalance in initial data caused spatial and temporal interpolations. $S_{\text {evap }}$ is taken from monthly surface evaporation fields by NASA GEOS- 1 reanalysis for 1992-1993, which are inconsistent with reanalysis used for advection and may induce additional errors in simulations. Underestimation of convective updraft may be a reason for underprediction of ${ }^{222} \mathrm{Rn}$ in the upper atmosphere in the previous version of NIES TM (Maksyutov et al., 2008). 
Convective and large-scale transport overlap significantly, and resolved winds in reanalysis dynamic fields intrinsically contain substantial information about convection (Lawrence and Salzmann, 2008). It is therefore necessary to further evaluate the proposed method using tests that consider the wider spectrum of processes that influence vertical transport.

\section{Validation of the parametrisation using ${ }^{222} R n$}

As global simulations of the short-lived tracer ${ }^{222} \mathrm{Rn}$ provide a very efficient means of evaluating convective parametrisations, in this section, the output of the NIES TM outfitted with the proposed convection scheme is compared with observational data and the output of TransCom- $\mathrm{CH}_{4}$ transport models.

\subsection{Intercomparison with TransCom- $\mathrm{CH}_{4}$ transport models}

Observational measurements of ${ }^{222} \mathrm{Rn}$ are currently sparse and insufficient to adequately define global and regional radon profile climatologies. It is therefore impossible to evaluate a cumulus convection parametrisation in different latitudinal zones using observations alone. In this study, the output of the NIES TM with the proposed convection scheme is compared with the results of radon simulations performed by other transport models during the TransCom- $\mathrm{CH}_{4}$ TMI. We should note that the version of NIES TM considered here with the deep cloud parametrisation scheme described in Sect. 2 is same to the model that participated in the TransCom- $\mathrm{CH}_{4}$ intercomparison, which covers the period 1990-2007.

The ten additional CTMs that participated in the TransCom- $\mathrm{CH}_{4}$ TMI and simulated ${ }^{222} \mathrm{Rn}$ fields include the Australian Community Climate and Earth-System Simulator (ACCESS; Corbin and Law, 2011) the Atmospheric general circulation model-based CTM (ACTM; Patra et al., 2009), the Community Atmosphere Model (CAM; Gent et al., 2009), CSIRO Conformal-cubic Atmospheric Model (CCAM; Law et al., 2006), Goddard Earth Observing System Chemical transport model (GEOS-Chem; Fraser et al., 2011), The ECMWF Integrated Forecast System (IFS; Bechtold et al., 2004; http://www.ecmwf.int/research/ifsdocs/ CY36r1/index.html), the Integrated Massively Parallel Atmospheric Chemical Transport (IMPACT; Rotman et al., 2004), Model for OZone And Related chemical Tracers version 4 (MOZART; Emmons et al., 2010), the Goddard Space Flight Center Parameterized Chemistry and Transport Model (PCTM; Kawa et al., 2004), the Transport Model 5 (TM5; Krol et al., 2005) and the TOMCAT CTM (Chipperfield, 2006) models (Table 2).

Four of the model simulations were run in online configurations (ACCESS, ACTM, CCAM and IFS) while the remaining models were run in offline configurations. The
Tiedtke (1989) parametrisation scheme is used in four of the models (CCAM, IFS, TM5 and TOMCAT) and the Zhang and McFarlane (1995) parametrisation scheme is used in three (CAM, MOZART and PCTM). The horizontal resolutions range from $0.7^{\circ} \times 0.7^{\circ}$ to $6^{\circ} \times 4^{\circ}$ (longitude $\times$ latitude), and the number of vertical levels varies from a low of 18 to a high of 67 (see Table 2).

The comparison of the NIES and PCTM transport model is very useful, as the PCTM model is unique in supporting this dynamical convection study (Sect. 3) because it uses NASA GEOS-5 MERRA to perform the TransCom-CH4 simulation for the whole $18 \mathrm{yr}$. Therefore, the PCTM results facilitate the study of MERRA dynamic fields in conjunction with cloud and precipitation analyses.

\subsection{Geographical distribution of ${ }^{222} \mathrm{Rn}$}

The modelled distributions of mean radon concentrations at $900 \mathrm{hPa}$ are very heterogeneous (Fig. 4). The highest concentrations are located over the continents, with magnitudes of $800-1000 \times 10^{-21} \mathrm{~mol} \mathrm{~mol}^{-1}$ during January and 600 $800 \times 10^{-21} \mathrm{~mol} \mathrm{~mol}^{-1}$ during July. Radon concentrations are very low over open oceans, consistent with the low emissions in these regions. Concentrations near coastal regions are slightly higher due to the greater influence of land emissions. Filaments of high radon concentration are sometimes transported large distances into the atmosphere over oceanic regions, such as between Africa and South America (Brost and Chatfield, 1989). These filaments typically occur, when the high stability of the atmosphere inhibits mass transfer into upper layers (Fig. 4). Both vertical mass transport and the global redistribution of mass between hemispheres are more intense during summer than during winter. This seasonal variability plays a large role in determining the alignment of the concentration field, leading to the absence of strong peaks in northern temperate latitudes and producing minima over Antarctica.

Among the considered models, ACCESS, CAM, GEOSChem, IMPACT, MOZART appear to be more diffusive, as they show relatively high radon concentration over the Arctic ocean in January (Fig. 4).

At $300 \mathrm{hPa}$, the radon concentration depends strongly on atmospheric stability and the intensity of vertical transport (Fig. 5). The highest radon concentrations at $300 \mathrm{hPa}$ are found over tropical Africa and South America year-round, and over Southeast Asia especially during the summertime rainy season (not shown). The locations of these maxima are consistent with the locations of the most intense convective updrafts and the land sources of ${ }^{222} \mathrm{Rn}$. Throughout the atmosphere, the lowest ${ }^{222} \mathrm{Rn}$ concentrations are year-round over the tropical Pacific Ocean. This minimum is associated with powerful convective updrafts pumping "clean" air upward from the boundary layer to the tropopause. Seasonal variations at $300 \mathrm{hPa}$ are generally smooth, and are most prominent in northern temperate latitudes. 
Table 2. Model descriptions.

\begin{tabular}{|c|c|c|c|c|c|}
\hline \multirow[t]{2}{*}{ Model } & \multirow[t]{2}{*}{ Type } & \multirow[t]{2}{*}{ Meteorology } & \multirow[t]{2}{*}{ Convection scheme } & \multicolumn{2}{|c|}{ Resolution } \\
\hline & & & & Horizontal & Vertical \\
\hline ACCESS & online & AGCM & $\begin{array}{l}\text { Adaptive detrainment, deep and } \\
\text { mid convection (Gregory and } \\
\text { Rowntree, 1990) }\end{array}$ & $3.75^{\circ} \times 2.5^{\circ}$ & 38 \\
\hline ACTM & online & NCEP2 & $\begin{array}{l}\text { Simplified Arakawa and } \\
\text { Schubert (1974) }\end{array}$ & $\sim 2.8^{\circ} \times 2.8^{\circ}$ & $67 \sigma$ \\
\hline CAM & offline & NCEP/NCAR & Zhang and McFarlane (1995) & $2.5^{\circ} \times \sim 1.9^{\circ}$ & $28 \sigma$ \\
\hline CCAM & online & NCEP & Tiedtke (1989) & $220 \mathrm{~km}$ & $18 \sigma$ \\
\hline GEOS-Chem & offline & $\begin{array}{l}\text { 1990-2006: } \\
\text { GEOS-4; } \\
\text { 2007: GEOS-5; }\end{array}$ & $\begin{array}{l}\text { Relaxed Arakawa-Schubert or } \\
\text { Hack (1994) and Zhang and } \\
\text { McFarlane (1995) }\end{array}$ & $2^{\circ} \times 2.5^{\circ}$ & $30 / 47 \eta$ \\
\hline IFS & online & $\begin{array}{l}\text { ECMWF } \\
\text { ERA-Interim }\end{array}$ & Tiedtke (1989) & $\sim 0.7^{\circ} \times 0.7^{\circ}$ & $60 \sigma$ \\
\hline IMPACT & offline & GSFC/GEOS5 & Rasch et al. (1997) & $\begin{array}{l}1.25^{\circ} \times 1.0^{\circ} \\
5.0^{\circ} \times 4.0^{\circ} *\end{array}$ & $55 \eta$ \\
\hline MOZART & offline & NCEP/NCAR & $\begin{array}{l}\text { Hack (1994); Zhang and } \\
\text { MacFarlane (1995) }\end{array}$ & $\sim 1.8^{\circ} \times 1.8^{\circ}$ & $28 \sigma$ \\
\hline NIES08i & offline & JRA-25/JCDAS & Proposed in this work & $2.5^{\circ} \times 2.5^{\circ}$ & $32 \sigma-\theta$ \\
\hline РCTM & offline & GSFC/GEOS5 & Zhang and McFarlane (1995) & $1.25^{\circ} \times 1.0^{\circ}$ & $58 \eta$ \\
\hline TM5 & offline & $\begin{array}{l}\text { ECMWF, } \\
\text { ERA-Interim }\end{array}$ & Tiedtke (1989) & $\begin{array}{l}1.0^{\circ} \times 1.0^{\circ} \\
4.0^{\circ} \times 6.0^{\circ} *\end{array}$ & $25 \eta$ \\
\hline TOMCAT & offline & $\begin{array}{l}\text { ECMWF, } \\
\text { ERA-40/Interim }\end{array}$ & Tiedtke (1989) & $\sim 2.8^{\circ} \times 2.8^{\circ}$ & $60 \eta$ \\
\hline
\end{tabular}

Here, $\sigma$ vertical coordinates are pressure divided by surface pressure; $\eta$ vertical coordinates are a hybrid sigma-pressure; $\sigma-\theta$ a hybrid sigma-isentropic vertical coordinates.

* in our analysis we usually use high-resolution model versions, excepting special indicated cases.

We analyzed total, middle and upper tropospheric (from the 850,500 and $300 \mathrm{hPa}$ levels to the tropopause) ${ }^{222} \mathrm{Rn}$ burdens averaged over one year (Table 3 ). The mean total burden averaged using data from 13 model versions (low and high resolution versions of IMPACT and TM5 were considered) is about $256 \mathrm{~g}$, that is about $20 \%$ larger than was estimated by Tost et al. (2010) for ECHAM5/MESSy, as different prescribed radon sources were used.

As most of the atmospheric ${ }^{222} \mathrm{Rn}$ is located in the troposphere, $26 \%$ of the ${ }^{222} \mathrm{Rn}$ burden is found below $850 \mathrm{hPa}$, $80 \%$ below $500 \mathrm{hPa}$ and more than $95 \%$ below $300 \mathrm{hPa}$. The smallest total burdens are found in PCTM, TM5 and TOMCAT. Relatively large burdens are found in ACTM, CAM, IFS and MOZART.

Fractions of the total burden for ACCESS, CAM, GEOS-Chem, IFS, IMPACT $\left(5.0^{\circ} \times 4.0^{\circ}\right)$, MOZART, TM5 $\left(6.0^{\circ} \times 4.0^{\circ}\right)$ are close to the average for all three cases. Among the considered models ACTM, IMPACT $\left(1.25^{\circ} \times 1.0^{\circ}\right)$, NIES and TM5 $\left(1.0^{\circ} \times 1.0^{\circ}\right)$ show the strongest penetrative mass flux due to deep cumulus convection, and PCTM and TOMCAT relatively weaker.

The higher horizontal resolution versions of both IMPACT and TM5 resulted in higher ${ }^{222} \mathrm{Rn}$ concentrations above $500 \mathrm{hPa}$ compared to their respective lower resolution simulations. The use of a high-resolution grid leads to a more detailed description of convective processes in the upper troposphere (Patra et al., 2011) or higher resolution improves the description of resolvable winds.

\subsection{Zonal mean radon concentration}

Patra et al. (2011) analysed the zonal mean concentrations of radon simulated by the TransCom- $\mathrm{CH} 4$ models. For instance, they used the simulated ${ }^{222} \mathrm{Rn}$ distributions over the South Asian monsoon region $\left(70^{\circ} \mathrm{E}\right)$ during boreal summer.

This study focuses on ${ }^{222} \mathrm{Rn}$ distributions over the oceanic regions of the western coastlines of Africa $\left(0-30^{\circ} \mathrm{S}, 5^{\circ} \mathrm{E}\right)$, where the proposed convection scheme underestimates convective mass fluxes in comparison to MERRA (Sect. 3.2). 

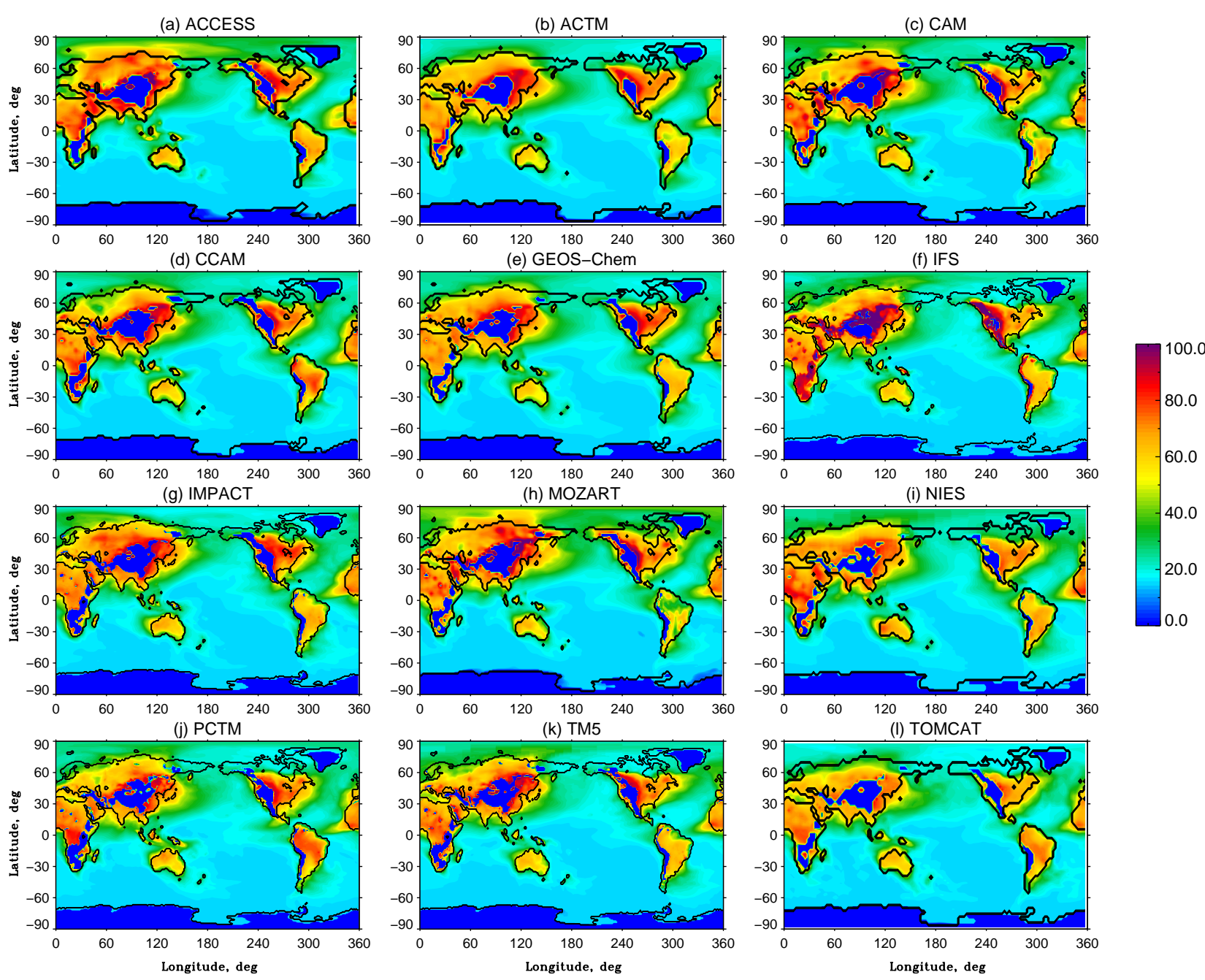

Fig. 4. Longitude-latitude distributions of ${ }^{222} \mathrm{Rn}$ concentrations $\left(10^{-21} \mathrm{~mol} \mathrm{~mol}^{-1}\right)$ at $900 \mathrm{hPa}$ during January as simulated by the eleven TransCom-CH4 models: (a) ACCESS, (b) ACTM, (c) CAM, (d) CCAM, (e) GEOS-Chem, (f) IFS, (g) IMPACT, (h) MOZART, (i) NIES08i, (j) PCTM, (k) TM5 and (l) TOMCAT.

Significant ${ }^{222} \mathrm{Rn}$ emissions occur north of the equator along $5^{\circ} \mathrm{E}$ longitude where land exists, while emissions are much smaller over the ocean to the south of the equator. The combination of the emission and powerful year-round convection results in strong vertical transport of ${ }^{222} \mathrm{Rn}$ throughout the year over $15^{\circ} \mathrm{S}-40^{\circ} \mathrm{N}$ (Fig. 6). This vertical transport extends upward to $100-200 \mathrm{hPa}$ in the upper troposphere. The location of the most intense convective transport fluctuates northward during boreal summer and southward during boreal winter, following the inter-tropical convergence zone (not shown). The NIES TM and ACTM produce notable areas of enhanced ${ }^{222} \mathrm{Rn}$ concentrations in the tropical upper troposphere between 200 and $300 \mathrm{hPa}$ (Fig. 6).

The lowest concentrations are located over the ocean (15$70^{\circ} \mathrm{S}$ ) and Antarctica (Fig. 6). Convective transport over Africa induces a steep gradient in radon concentrations throughout the troposphere south of $15^{\circ} \mathrm{S}$, especially during boreal winter, as shown by contour lines of radon concentrations in the troposphere that are approximately perpendicular to the surface.

Thus, the ${ }^{222} \mathrm{Rn}$ distributions calculated by NIES TM over regions with weak convective mass fluxes $\left(0-30^{\circ} \mathrm{S}, 5^{\circ} \mathrm{E}\right)$ is consistent with the TransCom-CH4 models results (Fig. 6). Apparently, insufficient reproduction of convective fluxes compared to MERRA in this area is compensated by convective activity in adjoining regions and other transport processes e.g., turbulent mixing and large-scale wind dynamics.

\subsection{Comparison of model results with observed vertical profiles}

In this section, the ability of the model simulations to capture the vertical structure of radon is evaluated using observations. Vertical profiles of ${ }^{222} \mathrm{Rn}$ mixing ratios in the 

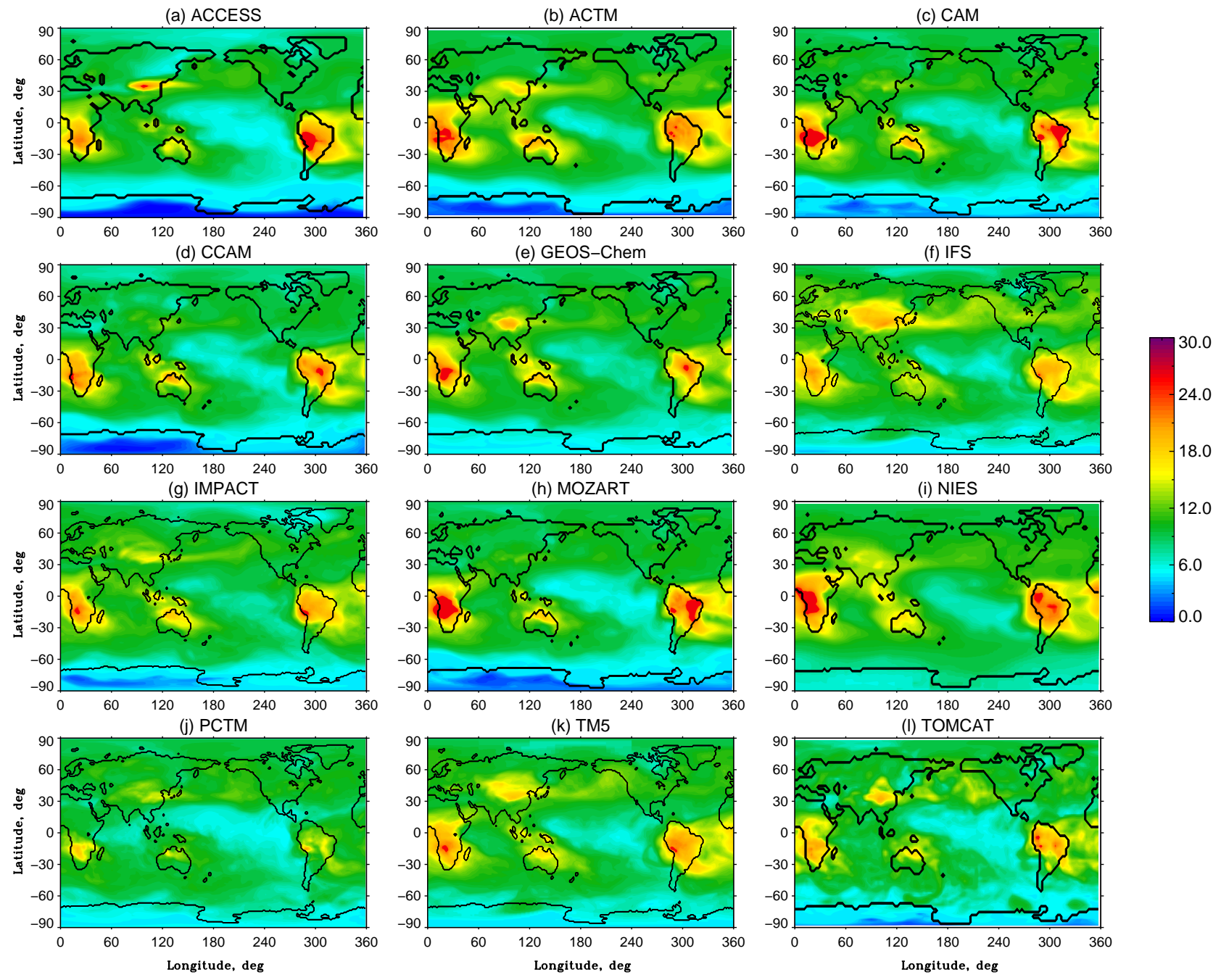

Fig. 5. As in Fig. 4, but at $300 \mathrm{hPa}$.

troposphere are available from aircraft observations (Liu et al., 1984; Zaucker et al., 1996; Kritz et al., 1998); however, the times at which these observations have been performed does not always overlap with the meteorological data used to drive the models. Patterns of advection can exert a large influence on the distribution of radon in the atmosphere. To limit weather-related differences, the validation is performed using only those composites of observational data that represent long-term (seasonal or annual) regional mean estimates of the vertical distribution of radon (Mahowald et al., 1995).

The set of summer and winter profiles for the Northern Hemisphere compiled by Liu et al. (1984) meets these criteria. Mean profiles are calculated for the period 1950-1972 at a variety of continental locations. The winter (DJF) mean profile includes data from seven sites, and the summer (JJA) mean profile includes data from 23 sites. Profiles of radon obtained in the free troposphere near Moffet Field, California $\left(37.5^{\circ} \mathrm{N}, 122.0^{\circ} \mathrm{W}\right)$ during the period 3 June-16 August
1994 (Kritz et al., 1998) are used in an independent comparison. These profiles extend from the surface to $11.5 \mathrm{~km}$ altitude, with typical measurement errors of $\sim 6 \%$. Measurements from nine flights associated with the North Atlantic Regional Experiment (NARE) during August 1993 (Zaucker et al., 1996) are used in a third independent comparison. These observations were taken over the North Atlantic Ocean and between Nova Scotia and New Brunswick in eastern Canada. Profiles of radon were taken from the surface to $5.5 \mathrm{~km}$ altitude, with estimated measurement errors of $\sim 15 \%$.

Figure 7 shows vertical profiles of ${ }^{222} \mathrm{Rn}$ over land areas in the mid-latitudes and tropics during the DJF and JJA seasons. The mean observational profiles compiled by Liu et al. (1984) are included in the panels corresponding to midlatitude land areas in the Northern Hemisphere (Fig. 7ab). The structure of the observed summer and winter profiles is approximately piecewise in three sections. Radon 

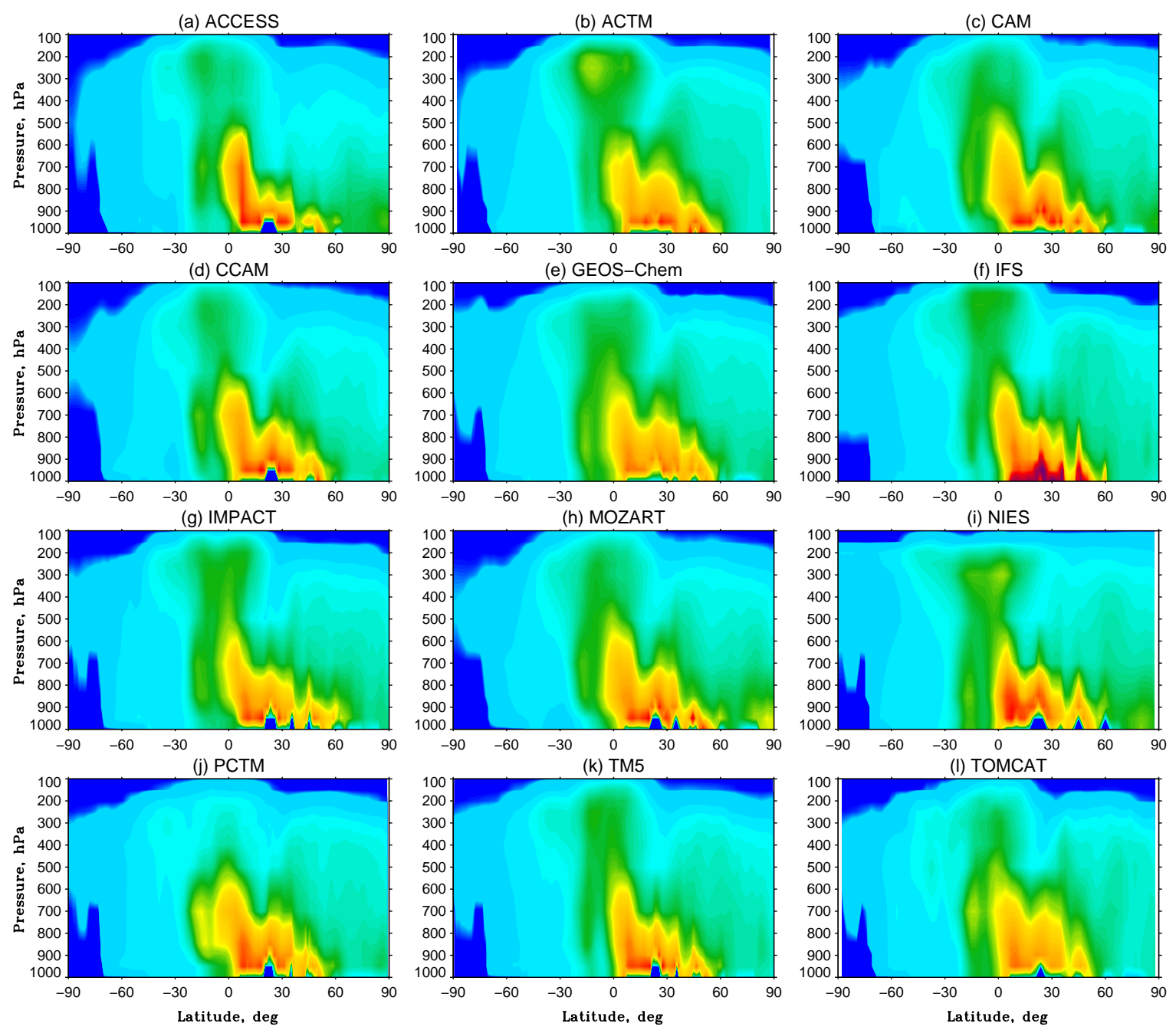

Fig. 6. Seasonal mean (DJF) latitude-pressure distributions of ${ }^{222} \mathrm{Rn}$ concentrations $\left(10^{-21} \mathrm{~mol} \mathrm{~mol}{ }^{-1}\right)$ along $5^{\circ} \mathrm{E}$ longitude as simulated by the TransCom-CH4 models for the year 2003: (a) ACCESS, (b) ACTM, (c) CAM, (d) CCAM, (e) GEOS-Chem, (f) IFS, (g) IMPACT, (h) MOZART, (i) NIES08i, (j) PCTM, (k) TM5 and (l) TOMCAT.

concentrations initially decrease at an approximately loglinear rate from the surface to $600 \mathrm{hPa}$. This rate of decrease is reduced between 600 and $250 \mathrm{hPa}$ and enhanced in the upper troposphere. During summer, the proposed convective scheme successfully captures the lower and middle components of this structure. Cold weather during winter in the Northern Hemisphere inhibits the development of convection over land so that convective precipitation rarely occurs (Fig. 3a). These conditions lead to a steep gradient in the mean vertical profile of radon concentration during this season, with a minimum in the middle atmosphere between 800 and $400 \mathrm{hPa}$ (Fig. 7a). All model profiles appear to be more uniform below $\sim 850 \mathrm{hPa}$ than the observations.

Figure 8 presents profiles of ${ }^{222} \mathrm{Rn}$ concentration over two coastal regions. The first region is near Moffett Field in California, USA (Fig. 8a); simulated profiles in this region are averaged over the month of June for comparison with the ob- served profiles initially presented by Kritz et al. (1998). The second region is off the eastern coast of Canada (Fig. 8b); simulated profiles in this region are averaged over the month of August for comparison with the observed profiles initially presented by Zaucker et al. (1996).

The simulated vertical structure of ${ }^{222} \mathrm{Rn}$ at Moffett Field during June corresponds well to the observed mean profile below $200 \mathrm{hPa}$. The discrepancy between model and observations above $200 \mathrm{hPa}$ was also seen by Zhang et al. (2008). Feng et al. (2011) suggested that CTMs generally underestimate the vertical extent of tropical convection, including mean cloud top height and convective mass fluxes in the upper most troposphere. The proposed convective parametrisation slightly overestimates the concentration of radon at the tops of convective cells because it overestimates organized outflow from convection at these levels (Fig. 8a). The concentration of ${ }^{222} \mathrm{Rn}$ decreases rapidly above this 
(a) $30^{\circ} \mathrm{N}-60^{\circ} \mathrm{N}$, Land, DJF

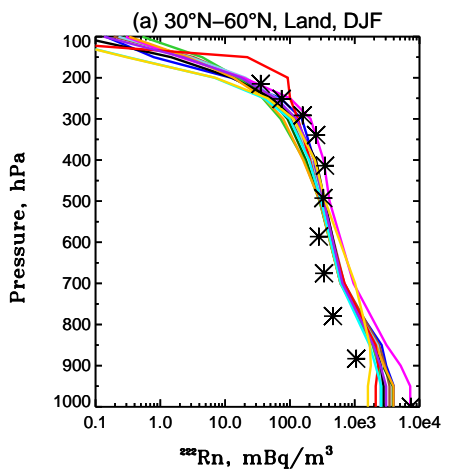

(d) $30^{\circ} \mathrm{S}-60^{\circ} \mathrm{S}$, Land, DJF

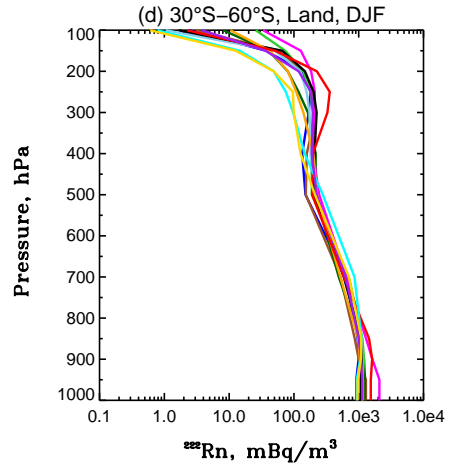

(b) $30^{\circ} \mathrm{N}-60^{\circ} \mathrm{N}$, Land, JJA

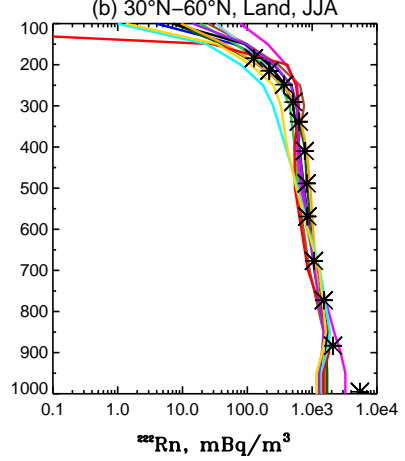

(e) $30^{\circ} \mathrm{S}-60^{\circ} \mathrm{S}$, Land, JJA

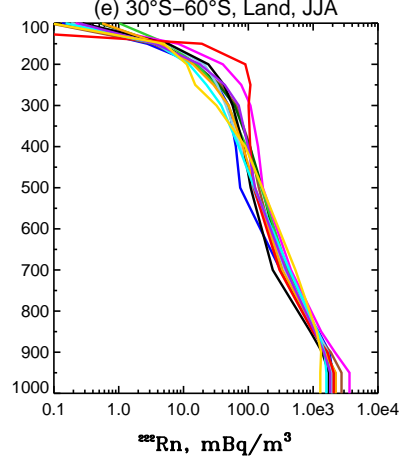

(c) $20^{\circ} \mathrm{S}-20^{\circ} \mathrm{N}$, Land

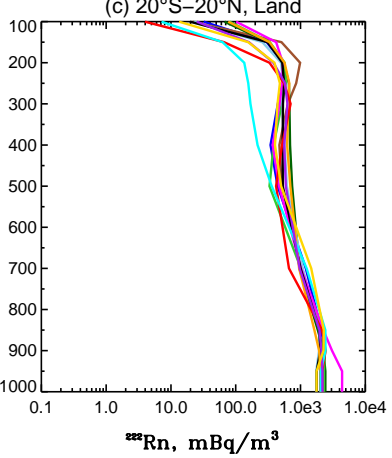

- ACCESS

- ACTM

- CAM

- CCAM

GEOS-Chem

- IFS

- IMPACT

- MOZART

- NIES

- PCTM

— TM5

TOMCAT

* Liu et al. (1984)

Fig. 7. Vertical profiles of radon concentration simulated by the different transport models for (a) land areas from $30-60^{\circ} \mathrm{N}$ during DJF, (b) land areas from $30-60^{\circ} \mathrm{N}$ during JJA, (c) land areas from $20^{\circ} \mathrm{S}-20^{\circ} \mathrm{N}$ year-round, (d) land areas from $30-60^{\circ} \mathrm{S}$ during DJF and (e) land areas from $30-60^{\circ} \mathrm{S}$ during JJA.

Table 3. The total ${ }^{222} \mathrm{Rn}$ burden (in $\mathrm{g}$ ) and upper tropospheric fractions of the total radon burden (in \%) averaged over a year.

\begin{tabular}{llcccc}
\hline$\#$ & Model & $\begin{array}{c}\text { Total } \\
\text { burden, g }\end{array}$ & $\begin{array}{c}\text { Fraction of } \\
\text { total burden for } \\
850-150 \mathrm{hPa}, \%\end{array}$ & $\begin{array}{c}\text { Fraction of } \\
\text { total burden for } \\
500-150 \mathrm{hPa}, \%\end{array}$ & $\begin{array}{c}\text { Fraction of } \\
\text { total burden for } \\
300-150 \mathrm{hPa}, \%\end{array}$ \\
\hline 1 & ACCESS & 255.3 & 73.3 & 19.3 & 5.6 \\
2 & ACTM & 267.8 & 71.3 & 24.3 & 7.9 \\
3 & CAM & 273.2 & 71.4 & 21.9 & 4.8 \\
4 & CCAM & 251.1 & 71.8 & 18.3 & 5.0 \\
5 & GEOS-Chem & 254.4 & 74.5 & 21.6 & 5.2 \\
6 & IFS & 288.4 & 71.8 & 21.4 & 6.7 \\
7 & IMPACT $\left(5.0^{\circ} \times 4.0^{\circ}\right)$ & 250.5 & 74.4 & 19.9 & 4.7 \\
8 & IMPACT $\left(1.25^{\circ} \times 1.0^{\circ}\right)$ & 252.2 & 75.0 & 22.6 & 5.7 \\
9 & MOZART & 265.5 & 71.4 & 21.4 & 5.0 \\
10 & NIES & $\mathbf{2 5 1 . 6}$ & $\mathbf{7 1 . 4}$ & $\mathbf{2 2 . 5}$ & $\mathbf{6 . 3}$ \\
11 & PCTM & 246.9 & 74.0 & 14.7 & 2.5 \\
12 & TM5 $\left(6.0^{\circ} \times 4.0^{\circ}\right)$ & 244.7 & 74.1 & 21.8 & 5.2 \\
13 & TM5 $\left(1.0^{\circ} \times 1.0^{\circ}\right)$ & 246.7 & 74.5 & 23.2 & 5.5 \\
14 & TOMCAT & 245.1 & 77.7 & 17.7 & 3.5 \\
\hline Averaged with standard deviation & $256.7 \pm 12.6$ & $73.3 \pm 1.9$ & $20.8 \pm 2.5$ & $5.3 \pm 1.3$ \\
\hline
\end{tabular}



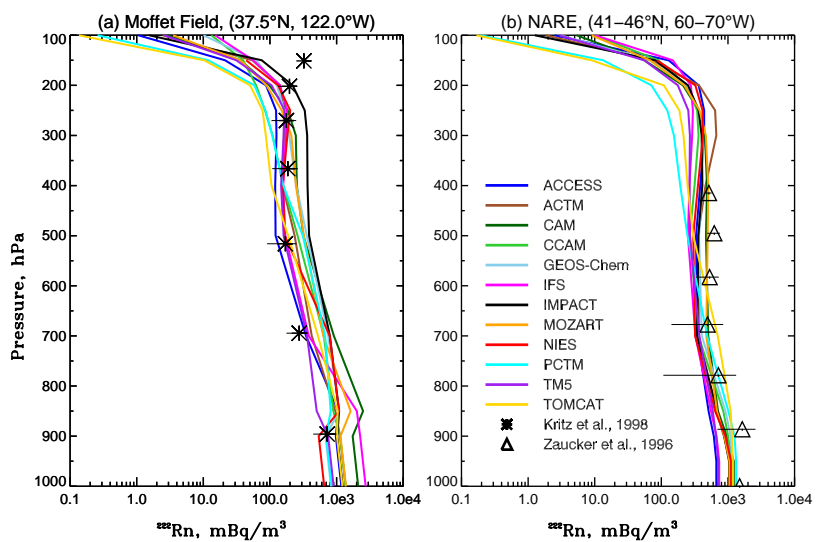

Fig. 8. Comparison of simulated and observed profiles of ${ }^{222} \mathrm{Rn}$ concentration from (a) the Moffet Field aircraft campaign and (b) the North Atlantic Regional Experiment aircraft campaign. The coloured lines are the results of the different transport models; the black symbols are observations. Horizontal error bars indicate the standard deviations of the observational measurements.

level because of the implementation of isentropic vertical coordinates, which inhibits the transport of tracers into the stratosphere (Belikov et al., 2012).

The results of the proposed convective scheme agree well with observations of ${ }^{222} \mathrm{Rn}$ taken in the lower part of the troposphere during the NARE aircraft campaign (Fig. 8b). The observations are unavailable above $6 \mathrm{~km}$. The various models produce different profiles of radon concentration above this level; consequently, it is not currently possible to adequately validate the results of the convective parametrisation in this region.

The proposed convective parametrisation generally produces vertical profiles of radon concentration that are consistent with physical expectations. The vertical profiles simulated by the proposed parametrisation agree reasonably well with both observational measurements and vertical profiles simulated by the TransCom- $\mathrm{CH}_{4}$ models. In general, simulated radon mixing ratio decreases at a lower altitude in PCTM and TOMCAT compared to the other models (Figs. 7d, 8a, b).

\subsection{Comparison of model results with surface measurements}

The simulated surface ${ }^{222} \mathrm{Rn}$ concentrations are validated against in situ surface measurements by interpolating model output to the spatial coordinates and altitude of the observations. Simulated and observed time series of monthly mean concentrations of radon at four sites are shown in Fig. 9 (Feng et al., 2011), and simulated and observed seasonal cycles of radon at 12 sites are summarized in Fig. 10 (Zhang et al., 2008). Basic information about these measurements is presented in Table 4. Radon concentrations are reported in units of millibecquerel per cubic meter at standardized temperature $(273.15 \mathrm{~K})$ and pressure $(1013.25 \mathrm{hPa})\left(\mathrm{mBq} \mathrm{m}^{-3}\right.$ STP).

\subsubsection{Comparison with continuous measurements of ${ }^{222} \mathrm{Rn}$}

The models are able to reproduce the phase of monthly mean variations in radon concentrations at a variety of surface sites (Fig. 9). This comparison between simulations and observations indicates that the assumed radon emissions produce realistic seasonal variation of radon at the surface. However, producing of the realistic seasonal amplitude variation is complicated. Good results are obtained at the oceanic sites Amsterdam Island and Bermuda (Fig. 9a, b), since these sites are mainly affected by large-scale transport (Zhang et al., 2008). All of the models overestimate summer concentrations of ${ }^{222} \mathrm{Rn}$ at Amsterdam Island (Fig. 9a).

Similar to the results presented by Zhang et al. (2008) and Feng et al. (2011), the model simulations evaluated in this paper show large discrepancies at the continental European station Hohenpeissenberg (Fig. 9c). Complicating factors in the model-measurement comparison include the strong dependence of observed surface ${ }^{222} \mathrm{Rn}$ on the structure of the boundary layer, the coarse horizontal resolution of the models and the possible errors in estimation of local emissions in the ${ }^{222} \mathrm{Rn}$ fluxes used in the simulations (Jacob et al., 1997). We have to note that the observed concentration data have high scatter about $2.0-2.5 \mathrm{mBq} \mathrm{m}^{-3}$. The majority of the models are successful in reproducing the monthly variations at Cape Grim (Fig. 9d). The exception is ACCESS As a coastal site, the monthly variations are determined by meteorology (i.e. the proportion of time that air reaching the site is oceanic or continental in origin). ACCESS is unable to capture this variation since its transport is not nudged to analyses.

\subsubsection{Comparison with observed seasonal variations}

Figure 10 shows the seasonal variation of ${ }^{222} \mathrm{Rn}$ concentrations at continental sites (Fig. 10a-d), remote island sites (Fig. 10e-h) and coastal sites (Fig. 10i-l). We also analyzed model-observation correlations, to obtain a quantified characteristic of the models performance (Fig. 11), despite high models biases and small seasonal cycle of the tracer.

The models qualitatively reproduce seasonal variability in radon concentration in Beijing (Fig. 10a), but the amplitude of this variability is severely underestimated. Zhang et al. (2008) reported that the annual mean of these measurements is a factor of two higher than the annual mean of measurements taken on the fourth floor of a building in Beijing (16 $\mathrm{m}$ above the ground). This discrepancy between observational datasets suggests that the model simulations may also properly characterize the annual mean concentration in Beijing. 
Table 4. Detailed information about the surface radon measurements used in this study.

\begin{tabular}{|c|c|c|c|c|}
\hline Site & Location & Type & Period & Source \\
\hline $\begin{array}{l}\text { Amsterdam Island, } \\
\text { France }\end{array}$ & $37.50^{\circ} \mathrm{S}, 77.30^{\circ} \mathrm{E}$ & Oceanic & $1981-2001$ & Ramonet et al. (2003) \\
\hline Bermuda, United States & $32.20^{\circ} \mathrm{N}, 64.40^{\circ} \mathrm{W}$ & Oceanic & 1991-1996 & Hutter et al. (1995) \\
\hline $\begin{array}{l}\text { Hohenpeissenberg, } \\
\text { Germany }\end{array}$ & $47.50^{\circ} \mathrm{N}, 11.00^{\circ} \mathrm{E}$ & Continental & 1999-2006 & Zellweger et al. (2006) \\
\hline Cape Grim, Tasmania & $40.40^{\circ} \mathrm{S}, 144.40^{\circ} \mathrm{E}$ & Coastal & 2000-2001 & $\begin{array}{l}\text { Zahorowski and } \\
\text { Whittlestone (1999) }\end{array}$ \\
\hline Beijing, China & $39.60^{\circ} \mathrm{N}, 116.20^{\circ} \mathrm{E}$ & Continental & 2003 & Zhang et al. (2004) \\
\hline Socorro, United States & $34.10^{\circ} \mathrm{N}, 106.90^{\circ} \mathrm{W}$ & Continental & $1951-1956$ & Wilkening (1959) \\
\hline Cincinnati, United States & $39.13^{\circ} \mathrm{N}, 84.50^{\circ} \mathrm{W}$ & Continental & $1959-1963$ & Gold et al. (1964) \\
\hline Para, Brazil & $2.90^{\circ} \mathrm{S}, 55.00^{\circ} \mathrm{W}$ & Continental & 2000.07-2004.12 & Martens et al. (2004) \\
\hline Crozet Island & $46.45^{\circ} \mathrm{S}, 51.85^{\circ} \mathrm{E}$ & Oceanic & 1993 & Dentener et al. (1999) \\
\hline Kerguelen & $49.30^{\circ} \mathrm{S}, 70.30^{\circ} \mathrm{E}$ & Oceanic & 1993 & Dentener et al. (1999) \\
\hline Dumont d'Urville & $66.00^{\circ} \mathrm{S}, 140.00^{\circ} \mathrm{E}$ & Oceanic & 1978.12-1979.11 & Heimann et al. (1990) \\
\hline $\begin{array}{l}\text { Mauna Loa, United } \\
\text { States }\end{array}$ & $19.53^{\circ} \mathrm{N}, 155.58^{\circ} \mathrm{E}$ & Oceanic & 1991-1996, 2001 & $\begin{array}{l}\text { Hutter et al. (1995) } \\
\text { and Zahorowski et al. (2005) }\end{array}$ \\
\hline Gosan, Korea & $33.30^{\circ} \mathrm{N}, 126.15^{\circ} \mathrm{E}$ & Coastal & 2001 & Zahorowski et al. (2005) \\
\hline Hong Kong, China & $22.20^{\circ} \mathrm{N}, 114.25^{\circ} \mathrm{E}$ & Coastal & 2001 & Zahorowski et al. (2005) \\
\hline Bombay, India & $18.90^{\circ} \mathrm{N}, 72.30^{\circ} \mathrm{E}$ & Coastal & 1966-1976 & Mishra et al. (1980) \\
\hline Livermore, United States & $37.70^{\circ} \mathrm{N}, 121.80^{\circ} \mathrm{W}$ & Coastal & $1965.05-1966.08$ & Lindeken (1966) \\
\hline
\end{tabular}

Socorro (Fig. 10b) and Cincinnati (Fig. 10c) are midlatitude sites with features similar to those observed in Beijing. The models are only able to reproduce observed concentrations at Socorro during the summer season, likely because the models are unable to capture the strong seasonal changes in wind direction and boundary layer depth that occur at Socorro. All models except ACTM show a negative correlation for Socorro (Fig. 11). Cincinnati is located in a transition zone between a humid subtropical climate and a humid continental climate. The model simulations clearly underestimate ${ }^{222} \mathrm{Rn}$ concentrations in Cincinnati during August-October (Fig. 10c).

At the Para station (Fig. 10d), radon observations are collected on a tower and include measurements taken both within and above the forest canopy ranging between $32 \mathrm{~m}$ and $61 \mathrm{~m}$ above ground level (we could not find measurements above the canopy only). The average measured concentration is quite high due to the lack of turbulent mixing in the canopy layer. Probably a mix of effects is seen in the model-data comparison: boundary layer stability, turbulent mixing as several models underestimate the concentration of ${ }^{222} \mathrm{Rn}$ at Para. The climate at Para is typical of a tropical rain- forest, resulting in small seasonal variations in radon concentrations. Correlations are quite mixed between models.

Concentrations of radon at isolated oceanic sites are affected primarily by large-scale transport rather than immediate emission and local circulation; it is therefore expected that simulated seasonal cycles of radon concentrations in these regions should match observations better than those in continental regions. Sites located in oceanic regions are characterized by much lower concentrations than continental sites, consistent with lower levels of emission (Fig. 10e-h).

Crozet (Fig. 10e) and Kerguelen (Fig. 10f) are located at high latitudes in the southern Indian Ocean. The model simulations qualitatively reproduce the seasonal cycles at these sites, including the maxima observed during austral winter; however, the simulated radon concentrations are generally too high. Local emissions are negligible, therefore the overestimated concentrations can only be attributed to long-range transport. The high concentrations of radon in this long-range transport likely originate in the southern regions of South America and Africa, as the prevailing winds at these sites are westerly year-round. Dentener et al. (1999) pointed out that positive biases in simulated ${ }^{222} \mathrm{Rn}$ concentrations at Crozet and Kerguelen result from overestimates of emission from 
(a) Amsterdam Island $\left(37.50^{\circ} \mathrm{S}, 77.30^{\circ} \mathrm{E}\right)$
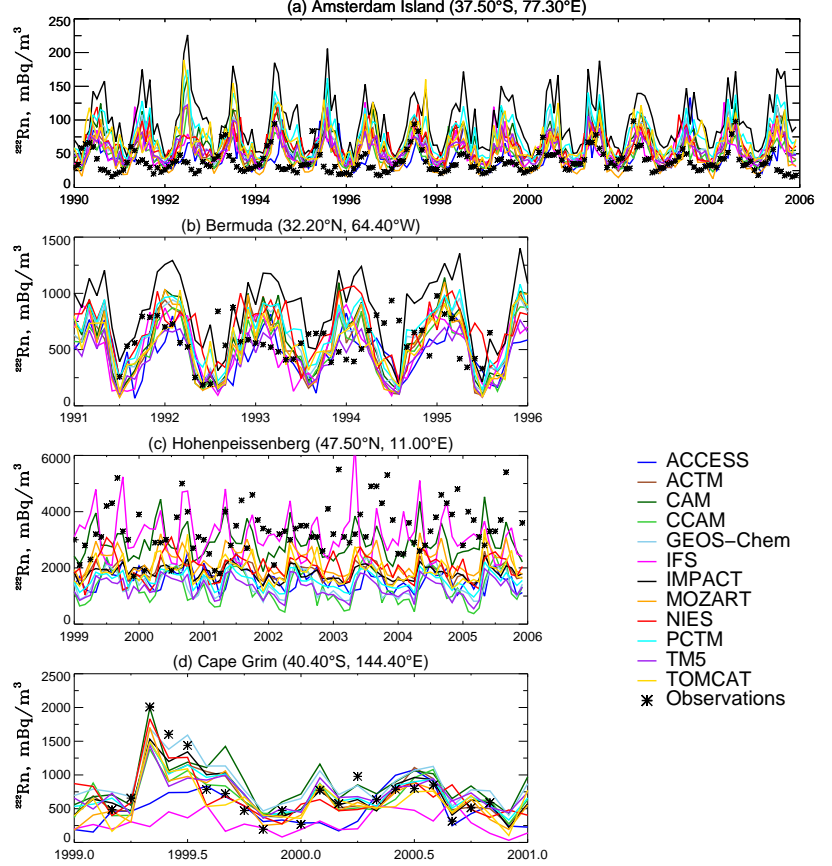

Fig. 9. Comparison of simulations and observations of near-surface ${ }^{222} \mathrm{Rn}$ concentration at (a) Amsterdam Island $\left(37.5^{\circ} \mathrm{S}, 77.3^{\circ} \mathrm{E}\right)$, (b) Bermuda $\left(32.2^{\circ} \mathrm{N}, 64.4^{\circ} \mathrm{W}\right)$, (c) Hohenpeissenberg $\left(47.5^{\circ} \mathrm{N}\right.$, $\left.11^{\circ} \mathrm{E}\right)$ and (d) Cape Grim $\left(40.4^{\circ} \mathrm{S}, 144.4^{\circ} \mathrm{E}\right)$. The colored lines are the results of the different transport models; the black symbols are observations. Note that the scales of the $\mathrm{x}$ - and $\mathrm{y}$-axes differ among the panels. Here we used results of low-resolution versions of IMPACT and TM5 models, as high-resolution data do not cover considered periods.

South America during austral winter months (i.e., frozen soil treated as non-frozen). Biases at these two sites should therefore not be considered as defects in the numerical models, but as limitations in the experimental design (Zhang et al., 2008). All models except TM5 can reproduce seasonal cycle $(r>0.5)$ (Fig. 11).

The observed seasonal cycle amplitude of radon concentrations at Dumont d'Urville (Fig. 10g) is similar to the seasonal cycles amplitude at Crozet and Kerguelen, but the annual maximum occurs during austral summer rather than during austral winter, so phase is shifted by 6 month. The positive biases in simulated concentrations between June and September have the same origin as the positive biases in simulated concentrations at the Southern Ocean stations during these months. The simulations assume that emission in these regions is zero year-round. A negative or small correlation is found for all models (Fig. 11).

The Hawaiian islands are large enough to produce nonnegligible local radon emissions, but too small to be resolved by global CTMs (Zhang et al., 2008). Incorrect radon source information is also culpable for the systematic low biases in simulated concentrations at Mauna Loa (Fig. 10h), while models performance in reproducing seasonality is good $(r \approx$ 0.5-0.8).

Figure 10i-1 shows simulated and observed seasonal cycles at coastal sites. Surface ${ }^{222} \mathrm{Rn}$ concentrations at coastal sites represent the complicated set of processes that occur in transitional zones between large continents and oceans. The accuracy of a simulated seasonal cycle of radon concentration in a coastal area therefore depends strongly on the ability of the model to realistically represent seasonal contrasts in wind direction and reproduce the detailed circulation in a relatively small region surrounding the site.

Gosan, Hong Kong and Bombay (Fig. 10i-k) are typical for sites in Asia, with monsoon-driven climates and complicated topography. The models are able to successfully reproduce the observed seasonal cycle $(r \approx 0.5-0.9)$. The simulated seasonal cycles at Livermore on the west coast of North America (Fig. 101) is less successful (only half of the models reproduce the seasonal cycle).

Simulated seasonal cycles in ${ }^{222} \mathrm{Rn}$ concentrations generally match observed seasonal cycles at oceanic and coastal sites as shown from comparison with MERRA and CMAP. The strength of vertical transport for some sites is overestimated by ACTM, which accordingly underestimates ${ }^{222} \mathrm{Rn}$ concentrations. At the same time, the results of this model show better agreement with the observed seasonal cycle. By contrast, IMPACT appears to be the model that overestimates concentrations. Outfitting the NIES TM with the proposed parametrisation scheme produces seasonal cycles similar to those simulated by TM5, but with higher amplitudes at Crozet, Kerguelen, Dumont and Bombay. Like the majority of the models considered in this analysis, NIES TM tends to overestimate ${ }^{222} \mathrm{Rn}$ at oceanic sites and is unable to successfully reproduce the complicated seasonal cycles at continental sites. However, the model agrees well with observations at coastal areas.

\section{Discussion}

The availability of global meteorological analysis and forecast products at fine resolutions makes it possible to resolve many dynamical features, but the lack of datasets that contain information about sub-grid scale processes creates challenges for the implementation of convective parametrisation schemes. The convective scheme presented in this work relaxes this limitation by linking vertical convective fluxes to convective precipitation rates. The proposed convective scheme can successfully reproduce deep cloud convection, as shown from comparison with MERRA reanalysis, radon vertical and near surface profiles. However, some issues should be discussed.

The proposed convection scheme underestimates the convective mass flux across significant areas (Fig. 3). The modeled convective rain rate is very different in different reanalysis datasets (Table 1, Figs. 2-3) as it highly depends on 

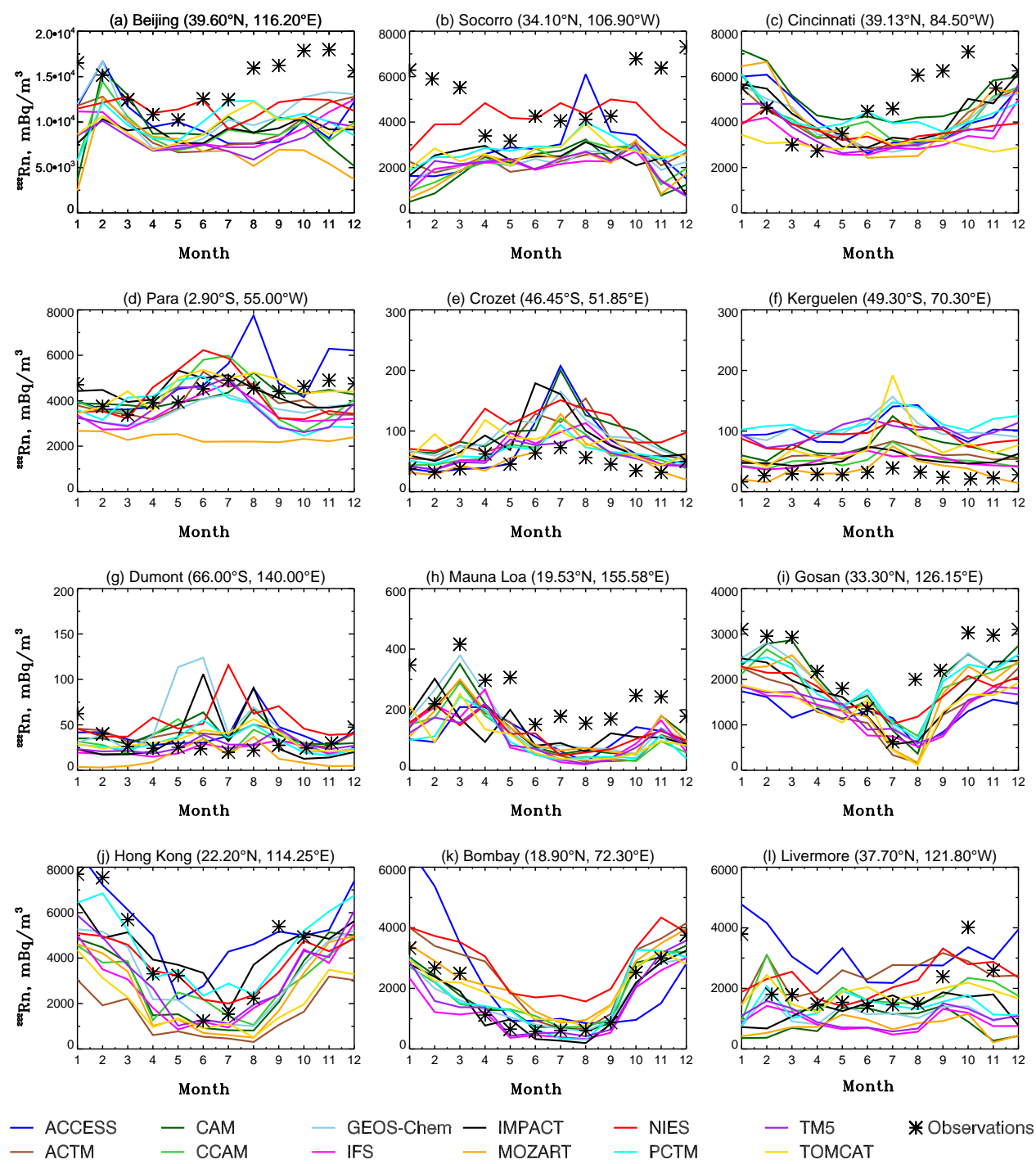

Fig. 10. Observed and simulated monthly mean surface radon concentration at continental (a-d), remote island (e-h) and coastal (i-l) sites . Note different scales for y-axes.

the convection scheme used, the model resolution and other model features. Therefore, it is difficult to know how much of the error shown in this work is due to the reanalysis product chosen and how much is due to the new convection scheme itself.

This model version employs a hybrid sigma-isentropic $(\sigma-\theta)$ vertical coordinate consisting of terrain-following and isentropic levels switched smoothly near the tropopause. Vertical transport in the isentropic part of the grid in the stratosphere was controlled by an air-ascending rate derived from the JRA-25/JCDAS reanalysis effective heating rate (Belikov et al., 2012). Due to such vertical coordinate NIES TM has more limited vertical transport in the upper troposphere/lower stratosphere region than every other model. As a result, the model with the new scheme has larger ${ }^{222} \mathrm{Rn}$ concentrations in the Northern Hemisphere above $200 \mathrm{hPa}$
(Fig. 6) and overestimates the concentrations in the levels around 200-150 hPa (Fig.7a, e).

To perform the TransCom- $\mathrm{CH}_{4}$ simulation for the whole 18 years the PCTM model uses NASA GEOS-5 MERRA reanalysis, which we used to study dynamical convection (Sect. 3) and evaluate convection mass flux calculated in NIES TM. The convection scheme of PCTM used for Transcom- $\mathrm{CH}_{4}$ activity is a semi-implicit convection module (i.e. CONV1 in Bian et al., 2006), constrained by the total convective mass flux (CMF) from MERRA, in which air parcels entrained at cloud base are transported upwards, detraining at a rate proportional to the convergence of MERRA CMF (Kawa et al., 2004).

It is worth noting that the convective transport algorithm used in the PCTM Transcom-CH4 study uses only the total net cloud flux of MERRA to solve a layer's mean mixing 


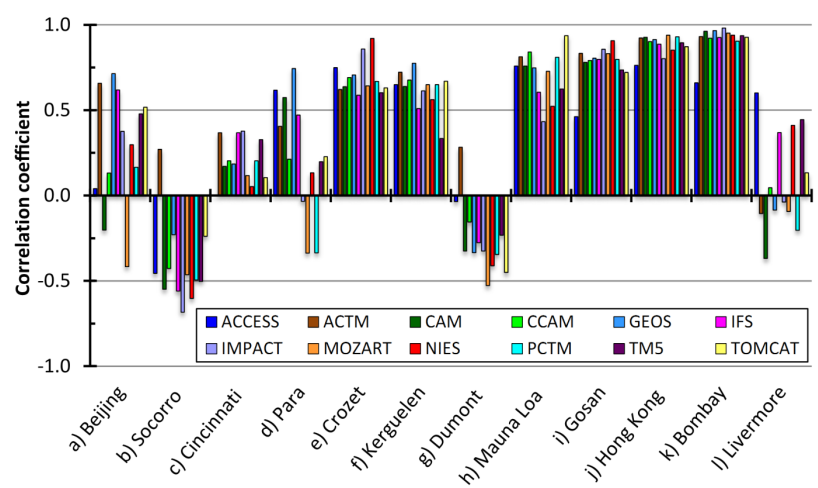

Fig. 11. Correlation coefficients between simulated and observed monthly mean surface ${ }^{222} \mathrm{Rn}$ concentration at continental (a-d), remote island $(\mathbf{e}-\mathbf{h})$ and coastal $(\mathbf{i}-\mathbf{l})$ sites.

ratio by exchanging with adjacent layers. There are two limitations in this approach: (1) tracer transport cannot proceed unmixed through more than one vertical grid cell per time step in penetrative cumulus; (2) the fluxes in opposite directions (updraft versus downdraft) are cancelled out by an equivalent amount in the total cloud mass flux. These limitations tend to decrease convective mixing relative to treating up and down drafts separately (refer details in Bian et al., 2006) and may explain the overall performance of PCTM radon vertical distribution discussed in this paper. The alternative convection in PCTM, named Conv2 in Bian et al. (2006), should, in theory, perform better since it keeps the tracer vertical transport in a penetrating cumulus consistent with the energy and moisture transport in its underlying GCM MERRA. GEOS-5/MERRA cloud transport, however, has been shown to systematically underestimate that from a cloud-resolving model (Ott et al., 2009) and to be highly sensitive to parameter values set in the cloud model. This work highlights that tracer transport depends not only on the reality of subgrid-scale physical parameterization in parent GCMs (e.g. MERRA), which is highly uncertain and representative only in a statistical sense in current models (Mahowald et al., 1995), but also on how convective quantities supplied by parent GCMs are used to constrain tracer transport in CTMs.

The convective mass flux calculated in NIES TM is in quite good agreement with the convective mass flux derived from MERRA over the continents. Over oceanic regions the convective mass flux is slightly underestimated by NIES TM though most of the large-scale upward convective transport, which is accompanied by convective precipitation, is captured. Nevertheless, the ${ }^{222} \mathrm{Rn}$ distributions calculated by NIES TM and PCTM are not very consistent.

In comparison to average values PCTM overestimates fractions of the total radon burden between 850 and $500 \mathrm{hPa}$, and underestimates it above $500 \mathrm{hPa}$. As a result, the top level of the radon distribution is considerably underestimated by PCTM. Conversely, in NIES TM, the vertical transport be- low/above $500 \mathrm{hPa}$ is slightly lower/higher than average respectively. Thus, the shape of convective mass flux distribution with height plays a critical role. Differences in largescale circulation and turbulent mixing could also provide an explanation.

Simulated seasonal cycles in ${ }^{222} \mathrm{Rn}$ concentrations generally consistent with observed seasonal cycles at continental, oceanic and coastal sites. In general, TransCom- $\mathrm{CH}_{4}$ models tend to overestimate ${ }^{222} \mathrm{Rn}$ at oceanic sites mainly due to uncertainty in local emissions and coarse models grids. However, model results agree well with observations at coastal sites, because seasonal cycles at such sites are driven by large-scale circulation. Reproducing the complicated seasonal cycles at continental sites is the most challenging. On the other hand, the model-to-model difference in ${ }^{222} \mathrm{Rn}$ concentration is still large indicating very different performance of DCC parameterizations. Results of NIES TM with offered parameterisation are consistent with the results of considered TransCom- $\mathrm{CH}_{4}$ on-line and off-line models. Unfortunately, carrying out a more detailed analysis to check model behavior is complicated due to a lack of observations.

Convective precipitation rates and other necessary parameters are calculated explicitly by GCMs and are available in reanalysis datasets at high spatial and temporal resolutions, so the NIES TM with described parameterization scheme may be employed using different reanalysis. For further work, it would be promising to analyze several reanalysis, investigate the parameterization sensitivity to parameter variation (i.e. $x_{1}$ in Eq. 6).

\section{Conclusions}

In this work, we presented the modified cumulus convection parametrisation scheme, which computes the mass of air transported upward in a cumulus cell using conservation of moisture and a detailed distribution of convective precipitation provided by JRA-25/JCDAS reanalysis dataset. This approach is more straightforward for off-line transport models, than the original Kuo-type scheme which integrates the total horizontal moisture convergence to calculate updraft mass flux, because the new scheme does not require to implement divergence operator to fields distorted by additional spatial and temporal interpolations. The proposed moist convection parametrisation was incorporated into the NIES offline global transport model, with the calculation of convective updraft mass fluxes based on convective precipitation rates taken from the JRA-25/JCDAS reanalysis. Necessary convective precipitation rate at the surface and the levels of cloud top and cloud base locations of cloud top and cloud base are provided by a meteorological dataset, as in this work, or estimated using the Kuo parametrisation scheme.

The JRA-25/JCDAS convective precipitation rate and simulated mass fluxes are compared with observations and reanalysis data. The convective precipitation data is evaluated 
by comparing it with monthly mean data from CMAP data and MERRA reanalysis. The MERRA analysis was also used to evaluate simulated convective mass fluxes calculated using the proposed scheme. The proposed convection scheme successfully captures most of the intensive upward convective mass flux that is accompanied by convective precipitation.

A simulation of the short-lived tracer ${ }^{222} \mathrm{Rn}$ is used to further evaluate the performance of the cumulus convection scheme. Simulated distributions of ${ }^{222} \mathrm{Rn}$ are validated against in situ observations from aircraft in the free troposphere and at surface stations, and compared with output from models that participated in the TransCom- $\mathrm{CH}_{4}$ Transport Model Intercomparison. Performed comparisons indicate the results obtained with proposed approach are in good agreement with observation in the tropics, where many important processes associated with cloud convection occur. Some revealed features in ${ }^{222} \mathrm{Rn}$ vertical distribution are caused by implementation of a hybrid sigma-isentropic $(\sigma-\theta)$ vertical coordinate. However, we demonstrate that the proposed convective scheme in general is consistent with observed and modeled results.

Acknowledgements. The authors are grateful to Kai Zhang (Pacific Northwest National Laboratory, Richland, USA) and Wuhu Feng (NCAS, University of Leeds, UK) for helpful comments and discussions. We thank Charmaine Franklin (CSIRO Marine and Atmospheric Research, Australia) for helpful comments on the manuscript. Annemarie Fraser is supported by the UK Natural Environment Research Council National Centre for Earth Observation. The contribution by the LLNL authors was prepared under Contract DE-AC52-07NA27344, with different parts supported by the IMPACTS project funded by the US DOE (BER) and project (07-ERD-064) funded by the LDRD program at LLNL. The JRA-25/JCDAS datasets used in this study were provided by the Japan Meteorological Agency. NIES TM numerical simulations were performed on the National Institute for Environmental Studies (NIES) supercomputer system (NEC SX-8R/128M16). The ACCESS model uses the Met Office Unified Model ${ }^{\text {TM }}$ (UK) with a CSIRO land-surface scheme (CABLE). ACCESS and CCAM simulations were undertaken as part of the Australian Climate Change Science Program and used the NCI National Facility in Canberra, Australia. The research leading to the IFS results has received funding from the European Community's Seventh Framework Programme (FP7 THEME [SPA.2011.1.5-02]) under grant agreement no. 283576 in the context of the MACC-II project (Monitoring Atmospheric Composition and Climate - Interim Implementation).

Edited by: C. Gerbig

\section{References}

Allen, D. J., Rood, R. B., Thompson, A. M., and Hudson, R. D.: Three-dimensional ${ }^{222} \mathrm{Rn}$ calculations using assimilated meteorological data and a convective mixing algorithm, J. Geophys. Res., 101, 6871-6881, 1996.

Arakawa, A.: The cumulus parameterization problem: Past, present, and future, J. Climate, 17, 2493-2525, 2004.

Arakawa, A. and Shubert, W. H.: Interaction of a cumulus ensemble with the large-scale environment, Part I, J. Atmos. Sci., 31, 674704, 1974.

Austin, P. M. and Houze Jr., R. A.: A technique for computing vertical transports by precipitating cumuli, J. Atmos. Sci., 30, 1100$1111,1973$.

Bechtold, P., Chaboureau, J., Beljaars, A., Betts, A., Köhler, M., Miller, M., and Redelsperger, J.-L.: The simulation of the diurnal cycle of convective precipitation over land in a global model, Q. J. Roy. Meteor. Soc., 130, 3119-3137, doi:10.1256/qj.03.103, 2004.

Belikov, D., Maksyutov, S., Miyasaka, T., Saeki, T., Zhuravlev, R., and Kiryushov, B.: Mass-conserving tracer transport modelling on a reduced latitude-longitude grid with NIES-TM, Geosci. Model Dev., 4, 207-222, doi:10.5194/gmd-4-207-2011, 2011.

Belikov, D. A., Maksyutov, S., Sherlock, V., Aoki, S., Deutscher, N. M., Dohe, S., Griffith, D., Kyro, E., Morino, I., Nakazawa, T., Notholt, J., Rettinger, M., Schneider, M., Sussmann, R., Toon, G. C., Wennberg, P. O., and Wunch, D.: Simulations of columnaverage $\mathrm{CO}_{2}$ and $\mathrm{CH}_{4}$ using the NIES TM with a hybrid sigmaisentropic $(\sigma-\theta)$ vertical coordinate, Atmos. Chem. Phys. Discuss., 12, 8053-8106, doi:10.5194/acpd-12-8053-2012, 2012.

Bian, H., Kawa, S. R., Chin, M., Pawson, S., Zhu, Z., Rasch, P., and $\mathrm{Wu}, \mathrm{S}$.: A test of sensitivity to convective transport in a global atmospheric $\mathrm{CO}_{2}$ simulation, Tellus B, 58, 463-475, doi:10.1111/j.1600-0889.2006.00212.x, 2006.

Brost, R. A. and Chatfield, R. B.: Transport of radon in a threedimensional, subhemispheric model, J. Geophys. Res., 94, 50955119, 1989.

Chipperfield, M. P.: New version of the TOMCAT/SLIMCAT offline chemical transport model: intercomparison of stratospheric tracer experiments, Quart. J. Roy. Meteor. Soc., 132, 1179-1203, 2006.

Conen, F.: Variation of ${ }^{222} \mathrm{Rn}$ Flux and its Implication for Tracer Studies, in: 1st International Expert Meeting on Sources and Measurements of Natural Radionuclides Applied to Climate and Air Quality Studies, WMO/GAW Report No.155, 83-85, March 2004.

Corbin, K. D. and Law, R. M.: Extending atmospheric $\mathrm{CO}_{2}$ and tracer capabilities in ACCESS, CAWCR Technical Report No. 35, The Centre for Australian Weather and Climate Re-search, ISBN: 978-1-921826-177, Aspendale, 2011.

Dentener, F., Feichter, J., and Jeuken, A.: Simulation of ${ }^{222}$ Rn using on-line and off-line global models, Tellus B, 51, 573-602, 1999.

Emmons, L. K., Walters, S., Hess, P. G., Lamarque, J.-F., Pfister, G. G., Fillmore, D., Granier, C., Guenther, A., Kinnison, D., Laepple, T., Orlando, J., Tie, X., Tyndall, G., Wiedinmyer, C., Baughcum, S. L., and Kloster, S.: Description and evaluation of the Model for Ozone and Related chemical Tracers, version 4 (MOZART-4), Geosci. Model Dev., 3, 43-67, doi:10.5194/gmd3-43-2010, 2010. 
Feichter, J. and Crutzen, P. J.: Parameterization of vertical transport due to deep cumulus convection in a global transport model and its evaluation with ${ }^{222} \mathrm{Rn}$ measurements, Tellus B, 42, 100-117, 1990.

Feng, W., Chipperfield, M. P., Dhomse, S., Monge-Sanz, B. M., Yang, X., Zhang, K., and Ramonet, M.: Evaluation of cloud convection and tracer transport in a three-dimensional chemical transport model, Atmos. Chem. Phys., 11, 5783-5803, doi:10.5194/acp-11-5783-2011, 2011.

Folkins, I., Loewenstein, M., Podolske, J., Oltmans, S. J., and Proffitt, M.: A barrier to vertical mixing at $14 \mathrm{~km}$ in the tropics: Evidence from ozone sondes and aircraft measurements, J. Geophys. Res., 104, 22095-22102, 1999.

Fraser, A., C. Chan Miller, P. I. Palmer, N. M. Deutscher, N. B. Jones, and Griffith, D. W. T.: The Australian methane budget: interpreting surface and train-borne measurements using a chemistry transport model, J. Geophys. Res., 116, D20306 doi:10.1029/2011JD015964, 2011.

Fueglistaler, S., Wernli, H., and Peter, T: Tropical troposphere-tostratosphere transport inferred from trajectory calculations, J. Geophys. Res., 109, D03108, doi:10.1029/2003JD004069, 2004.

Gent, P. R., Yeager, S. G., Neale, R. B., Levis, S., and Bailey, D. A.: Improvements in a half-degree atmosphere/land version of the CCSM, Clim. Dynam., 79, 25-58, 2009.

Gold, S., Barkhau, H. W., Shleien, B., and Kahn, B.: Measurement of naturally occurring radionuclides in air, in: Natural Radiation Environment, edited by: Adams, J. A. S. and Lowder, W. M., Chicago, University of Chicago Press, 1964.

Gregory, D. and Rowntree, P. R.: A mass flux convection scheme with representation of cloud ensemble characteristics and stability dependent closure, Mon. Weather Rev., 118, 1483-1506, 1990.

Grell, G., Dudhia, D., and Stauffer, D.: A description of the fifth-generation Penn State/NCAR Mesoscale Model (MM5), NCAR/TN-398, 122, 1994.

Hack, J. J., Boville, B. A., Briegleb, B. P., Kiehl, J. T., Rasch, P. J., and Williamson, D. L.: Description of the NCAR community climate model (CCM2), NCAR/TN-382, 108, 1993.

Heimann, M. and Keeling, C.: A three-dimensional model of atmospheric $\mathrm{CO}_{2}$ transport based on observed winds: 2: Model description and simulated tracer experiments, Geophys. Mon., 55, 237-275, 1989.

Heimann, M., Monfray, P., and Polian, G.: Modeling the long-range transport of ${ }^{222} \mathrm{Rn}$ to subantarctic and arctic areas, Tellus B, 42, 83-99, 1990.

Hutter, A. R., Larsen, R. J., Maring, H., and Merrill, J. T.: ${ }^{222}$ Rn at Bermuda and Mauna Loa: Local and Distant Sources, J. Radioanal. Nucl. Ch., 193, 309-318, 1995.

Jacob, D. J., Prather, M.J., and Rasch, P. J.: Evaluation and intercomparison of global atmospheric transport models using ${ }^{222} \mathrm{Rn}$ and other short-lived tracers, J. Geophys. Res., 102, 5953-5970, 1997.

Johnson, R. H.: The role of convective-scale precipitation downdrafts in cumulus and synoptic scale interactions, J. Atmos. Sci., 33, 1890-1910, 1976.

Kawa, S. R., Erickson III, D. J., Pawson, S., and Zhu, Z.: Global $\mathrm{CO}_{2}$ transport simulations using meteorological data from the NASA data assimilation system, J. Geophys. Res., 109, D18312, doi:10.1029/2004JD004554, 2004.
Kritz, M. A., Rosner, S. W., and Stockwell, D. Z.: Validation of an off-line three-dimensional chemical transport model using observed radon profiles 1. Observations, J. Geophys. Res., 103, 8425-8432, 1998.

Krol, M., Houweling, S., Bregman, B., van den Broek, M., Segers, A., van Velthoven, P., Peters, W., Dentener, F., and Bergamaschi, P.: The two-way nested global chemistry-transport zoom model TM5: algorithm and applications, Atmos. Chem. Phys., 5, 417432, doi:10.5194/acp-5-417-2005, 2005.

Kuo, H. L.: On formation and intensification of tropical cyclones through latent heat release by cumulus convection, J. Atmos. Sci., 22, 40-63, 1965.

Kuo, H. L.: Further studies of the parameterization of the effect of cumulus convection on large scale flow, J. Atmos. Sci., 31, 12321240, 1974.

Kurihara, Y.: Numerical integration of the primitive equations on a spherical grid, Mon. Weather Rev., 93, 399-415, 1965.

Law, R. M., Kowalczyk, E. A., and Wang, Y. P.: Using atmospheric $\mathrm{CO}_{2}$ data to assess a simplified carbon-climate simulation for the 20th century, Tellus B, 53, 427-437, 2006.

Lawrence, M. G. and Rasch, P. J.: Tracer transport in deep convective updrafts: plume ensemble versus bulk formulations, J. Atmos. Sci., 62, 2880-2894, 2005.

Lawrence, M. G. and Salzmann, M.: On interpreting studies of tracer transport by deep cumulus convection and its effects on atmospheric chemistry, Atmos. Chem. Phys., 8, 6037-6050, doi:10.5194/acp-8-6037-2008, 2008.

Li, Y. and Chang, J. S.: A three-dimensional global episodic tracer transport model 1. Evaluation of its transport processes by ${ }^{222} \mathrm{Rn}$ simulations, J. Geophys. Res., 101, 25931-25947, 1996.

Lindeken, C. L.: Seasonal variations in the concentration of airborne radon and thoron daughters, USAEC Rep. UCRL-50007, University of California Lawrence Radiation Laboratory, Livermore, CA, 41-43, 1966.

Liu, S. C., McAfee, J. R., and Cicerone, R. J.: Radon-222 and tropospheric vertical transport, J. Geophys. Res., 89, 7291-7297, 1984.

Mahowald, N., Rasch, P., and Prinn, R.: Cumulus convection parameterizations in chemical transport models, J. Geophys. Res., 100, 26173-26189, 1995.

Mahowald, N., Rasch, P., Eaton, B., Whittlestone, S., and Prinn, R.: Transport of ${ }^{222} \mathrm{Rn}$ to the remote troposphere using MATCH and assimilated winds from ECMWF and NCEP/NCAR, J. Geophys. Res., 102, 28139-28152, 1997.

Maksyutov, S., Patra, P. K., Onishi, R., Saeki, T., and Nakazawa, T.: NIES/FRCGC global atmospheric tracer transport model: Description, validation, and surface sources and sinks inversion, J. Earth Simulator, 9, 3-18, 2008.

Martens, C. S., Shay, T. J., Mendlovitz, H. P., Matross, D. M., Saleska, S. R., Wofsy, S. C., Menton, W. S. W., Moura, M. C., Crill, P. M., De Moraes, O. L. L., and Lima, R. L.: Radon fluxes in tropical forest ecosystems of Brazilian Amazonia: nighttime $\mathrm{CO}_{2}$ net ecosystem exchange derived from radon and eddy covariance methods, Global Change Biol., 10, 618-629, 2004.

Mishra, U. C., Rangarajan, C., and Eapen, C. D.: Natural radioactivity of the atmosphere over the Indian land mass, inside deep mines, and over adjoining oceans, Natural Radiation Environment III. US Department of Energy, Special Symposium Series 51, CONF 780422, US Department of Energy, Washington, DC, 
327-346, 1980.

Mizuta, R., Oouchi, K., Yoshimura, H., Noda, A., Katayama, K., Yukimoto, S., Hosaka, M., and Kusunoki, S.: 20-km-mesh global climate simulations using JMA-GSM model - Mean climate state, J. Meteor. Soc. Japan, 84, 165-185, 2006.

Myoung, B. and Nielsen-Gammon, J. W.: Sensitivity of monthly convective precipitation to environmental conditions, J. Climate, 23, 166-188, 2010.

Olivié, D. J. L., van Velthoven, P. F. J., Beljaars, A. C. M., and Kelder, H. M., 2004: Comparison between archived and off-line diagnosed convective mass fluxes in the chemistry transport model TM3, J. Geophys. Res., 109, D11303, doi:10.1029/2003JD004036, 2004.

Onogi, K., Tsutsui, J., Koide, H., Sakamoto, M., Kobayashi, S., Hatsushika, H., Matsumoto, T., Yamazaki, N., Kamahori, H., Takahashi, K., Kadokura, S., Wada, K., Kato, K., Oyama, R., Ose, T., Mannoji, N., and Taira, R.: The JRA-25 Reanalysis, J. Meteor. Soc. Japan, 85, 369-432, 2007.

Ott, L. E., Bacmeister, J., Pawson, S., Pickering, K., Stenchikov, G., Suarez, M., Huntrieser, H., Loewenstein, M., Lopez, J., and Xueref-Remy,, I.: Analysis of convective transport and parameter sensitivity in a single column version of the Goddard earth observation system, version 5, general circulation model, J. Atmos. Sci., 66, 627-646, 2009.

Patra, P. K., Takigawa, M., Ishijima, K., Choi, B., Cunnold, D., Dlugokencky, E. J., Fraser, P., Gomez-Pelaez, A. J., Goo, T.-Y., Kim, J.-S., Krummel, P., Langenfelds, R., Meinhardt, F., Mukai, H., O’Doherty, S., Prinn, R. G., Simmonds, P., Steele, P., Tohjima, Y., Tsuboi, K., Uhse, K., Weiss, R., Worthy, D., and Nakazawa, T.: Growth rate, seasonal, synoptic, diurnal variations and budget of methane in the lower atmosphere, J. Meteor. Soc. Japan, 87, 635-663, 2009.

Patra, P. K., Houweling, S., Krol, M., Bousquet, P., Belikov, D., Bergmann, D., Bian, H., Cameron-Smith, P., Chipperfield, M. P., Corbin, K., Fortems-Cheiney, A., Fraser, A., Gloor, E., Hess, P., Ito, A., Kawa, S. R., Law, R. M., Loh, Z., Maksyutov, S., Meng, L., Palmer, P. I., Prinn, R. G., Rigby, M., Saito, R., and Wilson, C.: TransCom model simulations of $\mathrm{CH}_{4}$ and related species: linking transport, surface flux and chemical loss with $\mathrm{CH}_{4}$ variability in the troposphere and lower stratosphere, Atmos. Chem. Phys., 11, 12813-12837, doi:10.5194/acp-11-12813-2011, 2011.

Putman, W. M. and Suarez, M.: Cloud-system resolving simulations with the NASA Goddard Earth Observing System global atmospheric model (GEOS-5), Geophys. Res. Lett., 38, L16809, doi:10.1029/2011GL048438, 2011.

Ramonet, M., Schmidt, M., Pèpin, L., Kazan, V., Picard, D., Filippi, D., Jourd'heuil, L., Valant, C., Monvoisin, G., Sarda, R., and Ciais, P.: The French Trace Gas Monitoring Program RAMCES, in: Report of the Eleventh WMO/IAEA Meeting of Experts on Carbon Dioxide Concentration and Related Tracer Measurement Techniques, WMO/GAW Report 148, edited by: Toru, S. and Kazuto, S., Tokyo, Japan, 136-148, 2003.

Rasch, P. J., Mahowald, N. M., and Eaton, B. E.: Representations of transport, convection and the hydrologic cycle in chemical transport models: Implications for the modeling of short-lived and soluble species, J. Geophys. Res., 102, 28127-28138, 1997.

Rotman, D. A., Atherton, C., Bergmann, D. J., Cameron-Smith, P. J., Chuang, C. C., Connell, P. S., Dignon, J. E., Franz, A., Grant, K. E., Kinnison, D. E., Molenkamp, C. R., Proctor,
D. D., and Tannahill, J. R.: IMPACT, the LLNL 3-D global atmospheric chemical transport model for the combined troposphere and stratosphere: model description and analysis of ozone and other trace gases, J. Geophys. Res., 109, D04303, doi:10.1029/2002JD003155, 2004.

Schumacher, C. and Houze, Jr., R. A.: Stratiform rain in the tropics as seen by the TRMM Precipitation Radar, J. Climate, 16, 17391756, 2003.

Stockwell, D. Z., Kritz, M. A., Chipperfield, M. P., and Pyle, J. A.: Validation of an off-line 3-D chemical transport model using observed radon profiles - Part II: Description of the model and results, J. Geophys. Res., 103, 8433-8445, 1998.

Tiedtke, M.: A comprehensive mass flux scheme for cumulus parameterization in large scale models, Mon. Weather Rev., 117, 1779-1800, 1989.

Tost, H., Lawrence, M. G., Brühl, C., Jöckel, P., The GABRIEL Team, and The SCOUT-O3-DARWIN/ACTIVE Team: Uncertainties in atmospheric chemistry modelling due to convection parameterisations and subsequent scavenging, Atmos. Chem Phys., 10, 1931-1951, doi:10.5194/acp-10-1931-2010, 2010.

Turner, J. S.: The motion of buoyant elements in turbulent surroundings, J. Fluid. Mech., 16, 1-16, 1963.

Wilkening, M. H.: Daily and annual courses of natural atmospheric radioactivity, J. Geophys. Res., 64, 521-526, 1959.

Wong, S., Fetzer, E. J., Kahn, B. H., Tian, B., Lambrigsten, B. H., and Ye, H.: Closing the global water budget with AIRS water vapor, MERRA winds and evaporation, and TRMM precipitation, J. Climate, 24, 6307-6321, 2011.

Xie, P. and Arkin, P. A.: Global precipitation: a 17-year monthly analysis based on gauge observations, satellite estimates, and numerical model outputs, B. Am. Meteor. Soc., 78, 2539-2558, 1997.

Zahorowski, W. and Whittlestone, S.: Radon database 1987-1996: a review, in: Baseline Atmospheric Program (Australia) 1996, edited by: Gras, J. L., Derek, N., Tindale, N. W., and Dick, A. L., Bureau of Meteorology and CSIRO Atmospheric Research, Melbourne, 71-80, 1999.

Zahorowski, W., Chambers, S., Wang, T., Kang, C.-H., Uno, I.,Poon, S., Oh, S.-N., Werczynski, S., Kim, J., and HendersonSellers, A.: Radon-222 in boundary layer and free tropospheric continental outflow events at the three ACE-Asian sites, Tellus, 57B, 124-140, 2005.

Zaucker, F., Daum, P. H., Wetterauer, U., Berkowitz, C., Kromer, B., and W. S. Broecker,: Atmospheric ${ }^{222} \mathrm{Rn}$ measurements during the 1993 NARE Intensive, J. Geophys. Res., 101, 29149-29164, 1996.

Zellweger, C., Klausen, J., and Buchmann, B.: System and Performance Audit of Surface Ozone and Carbon Monoxide at the Global GAW Station Hohenpeissenberg, Germany, WCC-Empa Report 06/3, WMO World Calibration Centre for Surface Ozone, Carbon Monoxide and Methane, Empa Dubendorf, Switzerland, 41 pp., 2006.

Zhang, G. J. and McFarlane, N. A.: Sensitivity of climate simulations to the parameterization of cumulus convection in the Canadian Climate Centre general circulation model, Atmos.-Ocean, 33, 407-446, 1995. 
Zhang, K., Wan, H., Zhang, M., and Wang, B.: Evaluation of the atmospheric transport in a GCM using radon measurements: sensitivity to cumulus convection parameterization, Atmos. Chem. Phys., 8, 2811-2832, doi:10.5194/acp-8-2811-2008, 2008.
Zhang, L. G., Guo, Q. J., and Iida, T.: Atmospheric radon levels in Beijing, China, Radiat. Prot. Dosim., 112, 449-453, 2004. 